\title{
Short-term changes in soil Munsell colour value, organic matter content and soil water repellency after a spring grassland fire in Lithuania
}

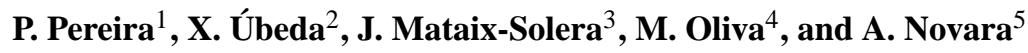 \\ ${ }^{1}$ Environmental Management Center, Mykolas Romeris University, Ateities g. 20, 08303 Vilnius, Lithuania \\ ${ }^{2}$ GRAM (Mediterranean Environmental Research Group), Department of Physical Geography and Regional Geographic \\ Analysis, University of Barcelona, Montalegre, 6, 08001 Barcelona, Spain \\ ${ }^{3}$ Environmental Soil Science Group, Department of Agrochemistry and Environment, Miguel Hernández University, Avda. de \\ la Universidad s/n, Elche, Alicante, Spain \\ ${ }^{4}$ Institute of Geography and Territorial Planning, University of Lisbon Alameda da Universidade, 1600-214, Lisbon, Portugal \\ ${ }^{5}$ Dipartimento di Scienze agrarie e forestali, University of Palermo, 90128 Palermo, Italy
}

Correspondence to: P. Pereira (paulo@mruni.eu)

Received: 25 October 2013 - Published in Solid Earth Discuss.: 22 November 2013

Revised: 21 February 2014 - Accepted: 3 March 2014 - Published: 11 April 2014

\begin{abstract}
Fire is a natural phenomenon with important implications on soil properties. The degree of this impact depends upon fire severity, the ecosystem affected, topography of the burned area and post-fire meteorological conditions. The study of fire effects on soil properties is fundamental to understand the impacts of this disturbance on ecosystems. The aim of this work was to study the short-term effects immediately after the fire (IAF), 2, 5, 7 and 9 months after a low-severity spring boreal grassland fire on soil colour value (assessed with the Munsell colour chart), soil organic matter content (SOM) and soil water repellency (SWR) in Lithuania. Four days after the fire a $400 \mathrm{~m}^{2}$ plot was delineated in an unburned and burned area with the same topographical characteristics. Soil samples were collected at $0-5 \mathrm{~cm}$ depth in a $20 \mathrm{~m} \times 20 \mathrm{~m}$ grid, with $5 \mathrm{~m}$ space between sampling points. In each plot 25 samples were collected (50 each sampling date) for a total of 250 samples for the whole study. SWR was assessed in fine earth $(<2 \mathrm{~mm})$ and sieve fractions of $2-1,1-0.5,0.5-0.25$ and $<0.25 \mathrm{~mm}$ from the 250 soil samples using the water drop penetration time (WDPT) method. The results showed that significant differences were only identified in the burned area. Fire darkened the soil significantly during the entire study period due to the incorporation of ash/charcoal into the topsoil (significant differences were found among plots for all sampling dates).
\end{abstract}

SOM was only significantly different among samples from the unburned area. The comparison between plots revealed that SOM was significantly higher in the first 2 months after the fire in the burned plot, compared to the unburned plot. SWR of the fine earth was significantly different in the burned and unburned plot among all sampling dates. SWR was significantly more severe only IAF and 2 months after the fire. In the unburned area SWR was significantly higher IAF, 2, 5 and 7 months later after than 9 months later. The comparison between plots showed that SWR was more severe in the burned plot during the first 2 months after the fire in relation to the unburned plot. Considering the different sieve fractions studied, in the burned plot SWR was significantly more severe in the first 7 months after the fire in the coarser fractions $(2-1$ and $1-0.5 \mathrm{~mm})$ and 9 months after in the finer fractions $(0.5-0.25$ and $<0.25 \mathrm{~mm})$. In relation to the unburned plot, SWR was significantly more severe in the size fractions $2-1$ and $<0.25 \mathrm{~mm}$, IAF, 5 and 7 months after the fire than 2 and 9 months later. In the 1-0.5- and 0.5$0.25 \mathrm{~mm}$-size fractions, SWR was significantly higher IAF, 2, 5 and 7 months after the fire than in the last sampling date. Significant differences in SWR were observed among the different sieve fractions in each plot, with exception of 2 and 9 months after the fire in the unburned plot. In most cases the finer fraction $(<0.25 \mathrm{~mm})$ was more water repellent than the 
others. The comparison between plots for each sieve fraction showed significant differences in all cases IAF, 2 and 5 months after the fire. Seven months after the fire significant differences were only observed in the finer fractions $(0.5-0.25$ and $<0.25 \mathrm{~mm})$ and after 9 months no significant differences were identified. The correlations between soil Munsell colour value and SOM were negatively significant in the burned and unburned areas. The correlations between Munsell colour value and SWR were only significant in the burned plot IAF, 2 and 7 months after the fire. In the case of the correlations between SOM and SWR, significant differences were only identified IAF and 2 months after the fire. The partial correlations (controlling for the effect of SOM) revealed that SOM had an important influence on the correlation between soil Munsell colour value and SWR in the burned plot IAF, 2 and 7 months after the fire.

\section{Introduction}

Fire is a natural phenomenon important to many ecosystems worldwide. It is accepted that fire plays an important role in plant adaptations and ecosystem development and distribution (Pausas and Kelley, 2009). It is well known that fire is a common occurrence and important disturbance in boreal ecosystems and a factor in the forest ecology of the region (Vanha-Majamaa et al., 2007). These ecosystems are strongly adapted to fire disturbance (Granstrom, 2001; Hylander, 2011; Pereira et al., 2013a, b). However, climate change, recent land-use change and fire suppression policies, may have important implications on the fire regime, fire severity and the role of fire in boreal environments (De Groot et al., 2013; Kouki et al., 2012; Van Bellen et al., 2010).

Fire has been recognized to be a soil-forming factor (Certini, 2014). Despite this, little research has been carried out on soil properties from boreal grassland ecosystems (Pereira et al., 2013a, c). The majority of studies on fire impacts on grassland soils have been carried out in tropical (Coetsee et al., 2010; Michelsen et al., 2004), subhumid (Knapp et al., 1998), desert (Ravi et al., 2009a; Whitford and Steinberger, 2012), arid (Vargas et al., 2012), semiarid (Dangi et al., 2010; Ravi et al., 2009b; Xu and Wan, 2008), temperate (Harris et al., 2007) and Mediterranean environments (Marti-Roura et al., 2013; Novara et al., 2013; Úbeda et al., 2005).

After a fire, the degree of direct and indirect impacts on soils (e.g. ash and soil erosion, water balance, organic matter, hydrophobicity, ash nutrient input, and microbiological changes) has consequences for the complex spatio-temporal distribution and availability of nutrients (Kinner and Moody, 2010; Malkinson and Wittenberg, 2011; Moody et al., 2013; Pereira et al., 2011; Sankey et al., 2012; Shakesby, 2011). The spatio-temporal extent of fire impacts depends on the fire severity, topography of the burned area and the post-fire meteorological conditions.
Fire can change soil colour. In fires of high severity the temperatures increase soil redness, especially at temperatures of $300-500^{\circ} \mathrm{C}$ (Terefe et al., 2008) or $>600^{\circ} \mathrm{C}$ (Ketterings and Bigham, 2000; Ulery and Graham, 1993), which is attributed to the destruction of the organic matter and increase in iron oxides such as hematite (Terefe et al., 2005). In contrast, low-severity fires darken the soil as a result of the incorporation of ash/charcoal into the soil surface and matrix (Eckmeier et al., 2007). These authors observed that soil lightness of colour had a significant negative correlation with charcoal carbon. Despite this knowledge, little is known about the soil lightness changes in the immediate period after the fire, when the major changes in soil properties and ash transport happen (Pereira et al., 2013a; Scharenbroch et al., 2012).

Few studies have been carried out about fire effects on soil colour lightness in comparison to unburned soils. Eckmeier et al. (2007) studied the effects of a slash-and-burn fire on soil lightness compared to soil in an unburned plot. However, the study was carried out immediately after the fire and 1 year after the fire. Major changes were not observed in detail in the year after the fire. The changes in soil lightness after fire can have implications for temperature (albedo increase or decrease) and microbiological activity (Certini, 2005; Gomez-Heras et al., 2006). Thus it is important to have high-resolution studies of fire effects on soil lightness.

Fire affects also the soil organic matter (SOM) chemical composition and quantity. Fire can increase or decrease SOM depending on the type of fire and severity, a parameter which considers the effects of biophysical variables such as topography, soil type, vegetation species and ecosystem affected (Certini et al., 2011; González-Peréz et al., 2004; Knicker, 2007). Low-severity fires can increase SOM in the immediate period after, due to the incorporation of charred material (De Marco et al., 2005), and high-severity fires tend to consume the major part of SOM due to the high temperatures (Neff et al., 2005). Depending on the rainfall and topography, important amounts of SOM can be also lost by erosion some months after a fire (Novara et al., 2011).

The soil Munsell colour value, chroma and hue are useful methods to estimate SOM content (Spielvogel et al., 2004; Viscarra Rossell et al., 2006). The Munsell colour value is used to describe the lightness of the soil, chroma measures the colour intensity and hue the shade of the soil (Thwaites, 2002). Usually, SOM content is negatively correlated with soil hue, value and chroma (Ibañez-Ascencio et al., 2013; Viscarra Rossell et al., 2006). However, this relationship depends on the SOM composition. In soils with high organic carbon, soil darkening is attributed to the composition and quantity of black humic substances (Schulze et al., 1993). Soil colour estimation has been carried out using visual observation in the field (Post et al., 1983), in a laboratory environment (Torrent et al., 1980; Scharenbroch et al., 2012), using diffuse reflectance spectrophotometers (Spielvogel et al., 
2004; Torrent and Barron, 1983) and more recently, smartphone applications (Gomez-Robledo et al., 2013).

It is widely known that fire can induce soil water repellency (SWR), with implications for soil infiltration, water and nutrient availability and an increase of runoff and erosion (DeBano et al., 2000; Mataix-Solera et al., 2013; Varela et al., 2005). The fire impacts on SWR depend on type of soil affected, temperature reached, fire severity, fire recurrence, time of residence, type and amount of vegetation combusted, ash produced and pre- and post-fire soil moisture content (Bodí et al., 2011; Doerr et al., 2000; Jordán et al., 2011; MacDonald and Huffman, 2004; Mataix-Solera and Doerr, 2004; Tessler at al., 2012; Vogelmann et al., 2012). Previous studies observed that after a fire, SWR is especially changed in soils that were wettable before the fire compared to those that are hydrophobic (Gimeno-Garcia et al., 2011). In wettable soils, fire usually increases SWR (Granged et al., 2011; Mataix-Solera and Doerr, 2004), meanwhile in hydrophobic soils, fire can slightly reduce or have no impact on SWR (Doerr et al., 1998; Jordán et al., 2011; Neris et al., 2013). However, this effect depends on fire severity. Rodriguez-Alleres et al. (2012) reported that moderate-to-high severity fires can increase SWR in naturally repellent soils. Soil heating increases SWR due the volatilization of organic compounds in the litter and topsoil. The heating of the soil surface layer develops a pressure gradient in the heated layer, causing the upward movement into the atmosphere of these compounds, while others move downwards. The decrease of soil temperature with depth forces SOM compounds to condense onto soil particles at or below the soil surface. Soil heating can redistribute and concentrate the natural substances in soil and litter, facilitate the bonding of these substances to soil particles, and increase their hydrophobicity as a result of conformational changes in their structural arrangement (Doerr et al., 2009). Heat changes the SOM composition through thermal alteration and chemical transformation. Heating also induces an increase in the content of aromatic compounds, the formation of complex high-molecularweight compounds and low-molecular-weight oxo- and hydroxyacids (Atanassova and Doerr, 2011). Soil moisture controls SWR. Doerr and Thomas (2000) observed in coarsetextured burned and unburned soils that SWR disappeared when soil moisture exceeded $28 \%$. MacDonald and Huffman (2004) noted soil moisture thresholds where soils became hydrophilic were $10 \%$ for unburned sites, $13 \%$ for areas burned with low severity and $26 \%$ for sites burned at moderate and high severity. Post-fire changes in SWR are not well understood. Doerr et al. (2009) stated that more detailed studies are needed to determine (i) the duration of fireinduced SWR in different vegetation types and (ii) the relative roles of physical, chemical, and biological factors in breaking down post-fire SWR.

Spring grassland fires are frequent in Lithuania. After the winter, farmers burn the dead grass in order to improve fields for spring and summer crops (Pereira et al., 2012a). Thus, it is important to know the effects of these fires on soil properties in order to understand the impacts of this practice and their persistence in time, especially in this environment where few studies have been carried out. This study contributes to a better understanding of fire effects and shortterm changes in soil properties in boreal grasslands. At this time, the use of fire for landscape management is forbidden in Lithuania but, frequently, farmers set fires and leave the area until the fires are extinguished, leading on many occasions to loss of infrastructure and impacts on natural resources (Mierauskas, 2012; Pereira et al., 2012a).

The aim of this work was to study the short-term temporal effects of a low-severity spring grassland fire on some surface soil properties $(0-5 \mathrm{~cm})$ such as soil colour value (assessed with the Munsell colour chart), SOM content and SWR, in order to observe if this grassland fire induced relevant shortterm impacts on these soil properties. The study focused on the upper soil layer because previous studies have shown that fire effects on soil are especially limited to the first 5 cm (Marion et al., 1991; Blank et al., 2003), and especially in low-severity fires, where soil temperatures rarely exceed $100^{\circ} \mathrm{C}$ at the surface and $50^{\circ} \mathrm{C}$ at $5 \mathrm{~cm}$ (Agee, 1973).

\section{Materials and methods}

\subsection{Study site and design}

On 15 April 2011 an area of 20-25 ha near Vilnius (Lithuania) was affected by a wildfire. The burned area is located at coordinates $54^{\circ} 42^{\prime} \mathrm{N}, 25^{\circ} 08^{\prime} \mathrm{E}$ with an elevation of $158 \mathrm{~m}$ a.s.l. (above sea level). According to the local farmers, the fire was attributed to human causes resulting from the burning of grass and wood residues (Pereira et al., 2012a). The characteristics of the study area are described in Table 1. Fire severity was considered low based on the predominance of black ash and unburned patches (Pereira et al., 2013a). Four days after the fire, a plot of $400 \mathrm{~m}^{2}$ was delineated $(20 \mathrm{~m} \times 20 \mathrm{~m}$, with a grid with $5 \mathrm{~m}$ spacing between sampling points) in an unburned and burned area with the same topographical characteristics (flat area). In total, 25 samples (topsoil, $0-5 \mathrm{~cm}$ ) were collected in each plot, immediately after burning (IAF) and 2, 5, 7 and 9 months later. Samples were stored in plastic bags, taken to the laboratory and airdried for $24 \mathrm{~h}$ to constant weight. Subsequently, the samples were carefully sieved through a $2 \mathrm{~mm}$ mesh.

\subsection{Laboratory analysis}

The soil colour value was assessed using the Munsell colour chart (Viscarra Rossel et al., 2006) in the $2 \mathrm{~mm}$ sieved fraction. The Munsell value gives information about soil darkness/lightness. Low values correspond to dark soils and high values to light soils (Eckmeier et al., 2007). All the soil value analyses were carried out by the same person under the same light conditions. SOM content was 
Table 1. Main characteristics of the study area.

\begin{tabular}{|c|c|}
\hline $\begin{array}{l}\text { Geological substrate } \\
\text { (Kadunas et al., 1999) }\end{array}$ & Glacio-lacustrine deposits \\
\hline Soil type (WRB, 2006) & Albeluvisols \\
\hline $\begin{array}{l}\mathrm{a}, \mathrm{b} \text { Texture (\% sand, silt and clay) } \\
\text { (USDA, 2004) }\end{array}$ & $\begin{array}{l}9.4( \pm 3.07), 63.5( \pm 8.14) \\
27.1( \pm 5.21)(\text { Silt loam })\end{array}$ \\
\hline${ }^{\mathrm{a}} \mathrm{pH}$ & $7.2( \pm 0.15)$ \\
\hline${ }^{\mathrm{a} O r g a n i c}$ matter content $(\%)$ & $6.5( \pm 1.16)$ \\
\hline $\begin{array}{l}\text { Mean annual rainfall (mm) } \\
\text { (Bukantis, 1994) }\end{array}$ & 735 \\
\hline $\begin{array}{l}\text { Mean annual temperature }\left({ }^{\circ} \mathrm{C}\right) \\
\text { (Bukantis, 1994) }\end{array}$ & 8.8 \\
\hline Dominant vegetation & $\begin{array}{l}\text { Fall dandelion (Leontodon } \\
\text { autumnalis L.) and sweet } \\
\text { vernal grass (Anthoxanthum } \\
\text { odaratum L.) }\end{array}$ \\
\hline
\end{tabular}

a Values based on unburned soil samples $(N=25)$.

b Sand: $2-0.05 \mathrm{~mm}$, silt: $0.05-0.002 \mathrm{~mm}$, clay: $<0.002 \mathrm{~mm}$.

estimated by the loss-on-ignition (LOI) method using approximately $1 \mathrm{~g}$ of soil heated to $900^{\circ} \mathrm{C}$ for $4 \mathrm{~h}$ (Avery and Bascomb, 1974) after drying at $105^{\circ} \mathrm{C}$ for $24 \mathrm{~h}$ to remove the moisture. LOI was calculated according to the formula LOI $=\left(\right.$ Weight $_{105}-$ Weight $\left._{900}\right) /$ Weight $\left._{105}\right) \times 100$.

Soil texture of unburned samples was analysed using the Bouyoucos method (Bouyoucos, 1936) and $\mathrm{pH}$ with $1: 2.5$ deionized water (Table 1). Soil water repellency was assessed in the samples sieved through the $2 \mathrm{~mm}$ mesh (fine earth) and in the subsamples of all of the 250 samples divided into different soil sieve fractions of $2-1,1-0.5,0.5-0.25$ and $<0.25 \mathrm{~mm}$, as used in previous studies (Jordán et al., 2011; Mataix-Solera and Doerr, 2004). Soil sieving was done on the dried samples and the separation of fractions was carried out carefully, in order to not destroy the aggregates (MataixSolera and Doerr, 2004). In total 1250 SWR subsamples were analysed. Between 5 and $7 \mathrm{~g}$ of soil of each sample and subsample were placed in $60 \mathrm{~mm}$ diameter plastic dishes and exposed to a controlled laboratory environment (temperature of $20^{\circ} \mathrm{C}$ and $50 \%$ of air relative humidity) for 1 week in order to avoid potential effects of atmospheric conditions on SWR (Doerr, 1998; Doerr et al., 2005). The persistence of SWR was measured with the water drop penetration time (WDPT) method that involves placing three drops of distilled water onto the soil surface and registering the time required for the complete penetration of the drops (Wessel, 1988). The average time of the three drops was used to assess the WDPT of each sample and subsample. WDPT classes were assessed according to Doerr (1998) (Table 2).
Table 2. WDPT classes used in this work. Water drop penetration time measured in seconds (s) (according to Doerr, 1998).

\begin{tabular}{lcccc}
\hline WDPT classes & Wettable & Low & Strong & Severe \\
\hline WDPT interval (s) & $<5$ & $6-60$ & $61-600$ & $601-3600$ \\
\hline
\end{tabular}

\subsection{Statistical analysis}

Data normality and homogeneity of the variances were tested with the Shapiro-Wilk test (Shapiro and Wilk, 1965) and Levene test, respectively. Data were considered normal and homogeneous at a $p>0.05$. In this study, data did not follow the normal distribution and displayed heteroscedasticity. Thus the alternative non-parametric Kruskal-Wallis ANOVA (analysis of variance) test (K-W) was used to analyse differences among sampling dates and SWR according to the aggregate sieve fractions in each plot. The comparison between plots was carried out with the Mann-Whitney $U$ test (MU). If significant differences at a $p<0.05$ were observed after the K-W test, a Tukey HSD (honestly significant difference) post-hoc test was applied.

Correlations between the variables were carried out with the Pearson coefficient of correlation after variables SQR transformation, in order for the data to meet normality requirements. In the case of SWR, the coefficient of correlation just considered the fine-earth samples. A partial correlation was carried out between Munsell colour value and SWR, using SOM content as a control variable in order to observe if SOM influenced the correlation between Munsell colour value and SWR. Significant correlations were considered at a $p<0.05$. Statistical analyses were carried out with STATISTICA 6.0 (Statsoft Inc., 2006).

\section{Results}

\subsection{Soil Munsell colour value}

The soil colour in the burned and unburned plots was in the soil Munsell 10YR hue for all the samples. The Munsell colour value was significantly different among sampling dates in the burned plot $(\mathrm{K}-\mathrm{W}=35.37, p<0.001)$, but not in the unburned area (K-W $=9.20, p>0.05)$ (Fig. 1). Soil was significantly darker in the burned than in the unburned plot for all sampling dates, IAF (MU $=1, p<0.001), 2$ months $(\mathrm{MU}=69, p<0.001), 5$ months $(\mathrm{MU}=46, p<0.001), 7$ months $(\mathrm{MU}=56, p<0.001)$ and 9 months later $(\mathrm{MU}=84$, $p<0.001)$.

\subsection{Soil organic matter}

SOM content was not significantly different among sampling dates in the burned plot $(\mathrm{K}-\mathrm{W}=6.60, p>0.05)$, but it was in the unburned area (K-W=20.96 $p<0.001)$ (Fig. 2). SOM 


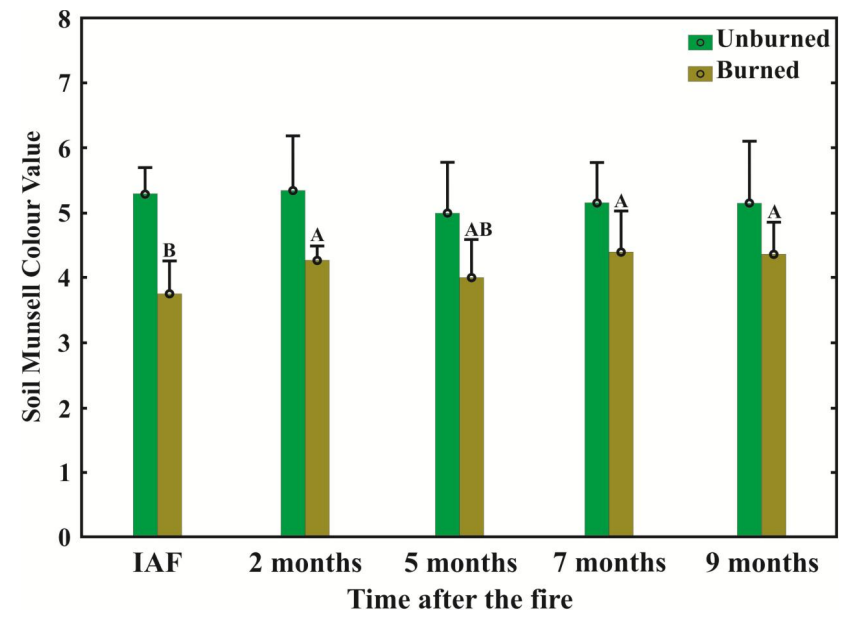

Fig. 1. Evolution of soil Munsell value in the unburned and burned plots in the post-fire sampling dates (bars represent \pm standard deviation). Different letters indicate significant differences $(p<0.05)$ among times. IAF (Immediately After the Fire).

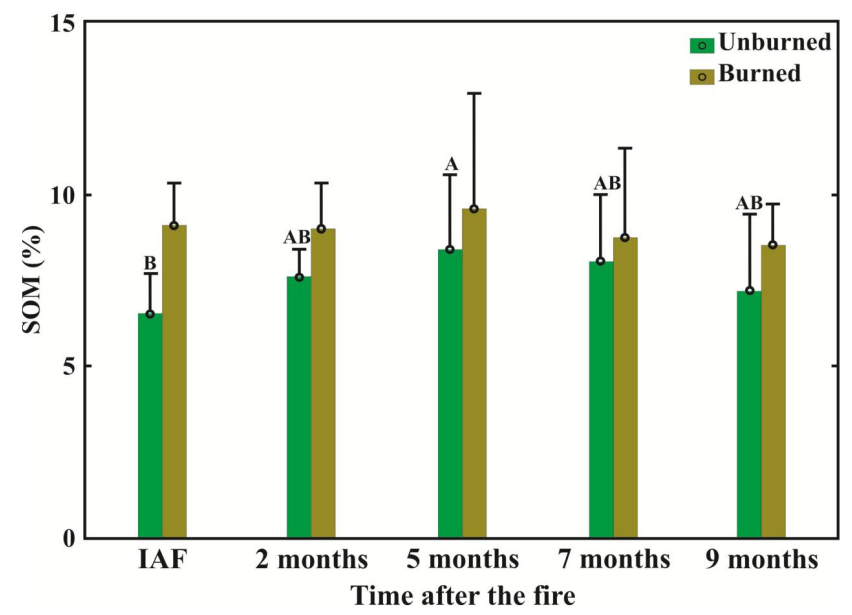

Fig. 2. Evolution of SOM content in the unburned and burned plots in the post-fire sampling dates (bars represent \pm standard deviation). Different letters indicate significant differences $(p<0.05)$ among times.

content was significantly higher in the burned plot than in the unburned plot IAF (MU $=31, p<0.001$ ) and 2 months after the fire (MU $=116, p<0.001)$. Five ( $\mathrm{MU}=266, p>0.05), 7$ $(\mathrm{MU}=299, p>0.05)$ and 9 months $(\mathrm{MU}=254, p>0.05)$ after the fire no significant differences were observed between plots.

\subsection{Soil water repellency}

The SWR of the fine earth was significantly different among sampling dates in the burned $(\mathrm{K}-\mathrm{W}=94.18, p<0.001)$ and unburned plots $(\mathrm{K}-\mathrm{W}=45.65, p<0.001)$ (Fig. 3). With time a decrease of SWR was observed in the burned area. In the unburned area SWR was significantly more severe IAF, 2,

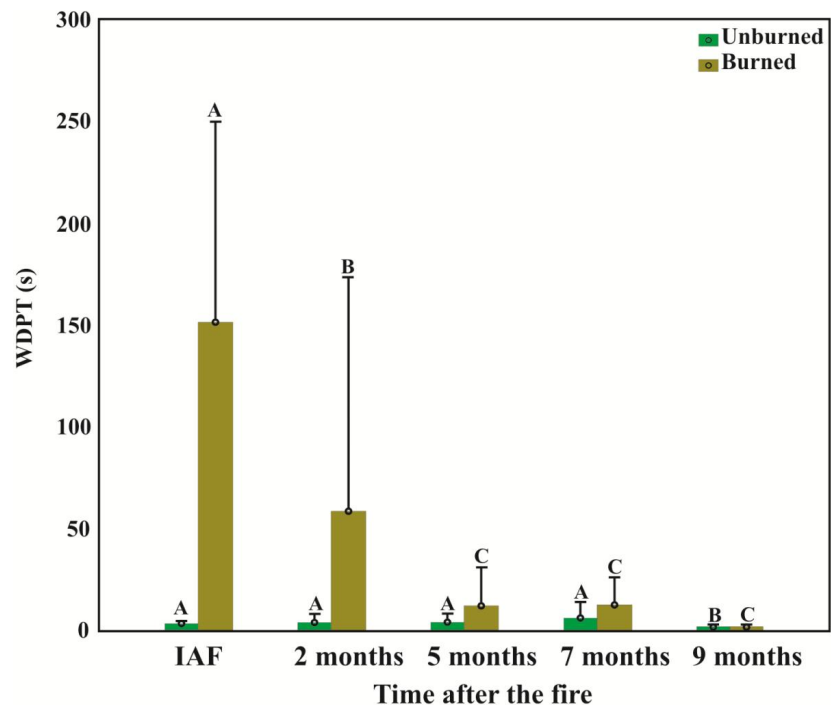

Fig. 3. Evolution of SWR (composite sample) in the unburned and burned plots in the post-fire sampling dates (bars represent \pm standard deviation). Different letters indicate significant differences $(p<0.05)$ among times.

5 and 7 months after the fire than 9 months later. SWR was significantly high in the burned soil in the first two sampling dates, IAF (MU $=0, p<0.001)$ and 2 months after the fire $(\mathrm{MU}=26, p<0.001)$. No significant differences were observed between plots 5 ( $\mathrm{MU}=249, p>0.05), 7(\mathrm{MU}=238$, $p>0.05)$ and 9 months $(\mathrm{MU}=267, p>0.05)$ after the fire.

In relation to the analysed sieved soil fractions, significant differences were observed in SWR among all sieve fractions in the burned and unburned areas (Table 3a). In the burned area significant differences were observed in the coarser sieve fractions $(2-1$ and $1-0.5 \mathrm{~mm})$ in the first 7 months after the fire, whereas in the finer fractions $(0.5$ 0.25 and $<0.25 \mathrm{~mm}$ ), significant differences among fractions were not identified until 9 months later (Table 4). In the unburned area's aggregate-size fractions of $2-1$ and $<0.25 \mathrm{~mm}$ SWR was more severe IAF, 5 and 7 months after the fire than 2 and 9 months after the fire. In the size fractions 1-0.5 and $0.5-0.25 \mathrm{~mm}$, SWR was significantly more persistent IAF, 2, 5 and 7 months after the fire than 9 months after the fire (Table 4).

The SWR was higher in the finer fractions $(0.5-0.25$ and $<0.25 \mathrm{~mm}$ ) than in the coarser fractions (2-1 and $1-0.5 \mathrm{~mm}$ ) (Table 4). Significant differences were observed in the studied sieve fractions in SWR in each plot during the experimental period, with the exception of 2 and 9 months after the fire in the unburned plot (Table $3 \mathrm{~b}$ ). In the unburned and burned plots for all sampling dates, the SWR in the finer fraction $(<0.25 \mathrm{~mm})$ was significantly more severe than in the other sieve fractions, except for IAF and 5 months after the fire in the unburned plot, where no significant differences were observed between $0.5-0.25 \mathrm{~mm}$ and $<0.25 \mathrm{~mm}$ sieve fractions 
Table 3. Results of Kruskal-Wallis ANOVA and Mann-Whitney tests for SWR according to the analysed sieved fractions, (a) time, (b) soil sieved fractions in the same plot and (c) between plots in each soil sieved fraction.

\begin{tabular}{|c|c|c|c|c|}
\hline \multirow[t]{9}{*}{ (a) } & $\begin{array}{l}\text { Sieved } \\
\text { fraction } \\
\mathrm{mm}\end{array}$ & Plots & $\mathrm{K}-\mathrm{W}$ & $p$ \\
\hline & \multirow[t]{2}{*}{$2-1$} & Unburned & 43.07 & $* * *$ \\
\hline & & Burned & 75.25 & $* * *$ \\
\hline & \multirow[t]{2}{*}{$1-0.5$} & Unburned & 35.39 & $* * *$ \\
\hline & & Burned & 78.17 & $* * *$ \\
\hline & \multirow[t]{2}{*}{$0.5-0.25$} & Unburned & 41.17 & $* * *$ \\
\hline & & Burned & 87.28 & $* * *$ \\
\hline & \multirow[t]{2}{*}{$<0.25$} & Unburned & 62.89 & $* * *$ \\
\hline & & Burned & 89.44 & $* * *$ \\
\hline \multirow[t]{11}{*}{ (b) } & $\begin{array}{l}\text { Sampling } \\
\text { date }\end{array}$ & Plot & $\mathrm{K}-\mathrm{W}$ & $p$ \\
\hline & \multirow[t]{2}{*}{ IAF } & Unburned & 25.14 & $* * *$ \\
\hline & & Burned & 33.29 & $* * *$ \\
\hline & \multirow[t]{2}{*}{2 months } & Unburned & 4.06 & n.s. \\
\hline & & Burned & 24.35 & $* * *$ \\
\hline & \multirow[t]{2}{*}{5 months } & Unburned & 41.30 & $* * *$ \\
\hline & & Burned & 9.07 & $*$ \\
\hline & \multirow[t]{2}{*}{7 months } & Unburned & 36.21 & $* * *$ \\
\hline & & Burned & 27.07 & $* * *$ \\
\hline & \multirow[t]{2}{*}{9 months } & Unburned & 4.25 & n.s. \\
\hline & & Burned & 8.60 & $*$ \\
\hline \multirow[t]{22}{*}{ (c) } & & Sieve & & \\
\hline & $\begin{array}{l}\text { Sampling } \\
\text { date }\end{array}$ & $\begin{array}{l}\text { fractions } \\
\mathrm{mm}\end{array}$ & MU & $p$ \\
\hline & \multirow[t]{4}{*}{ IAF } & $2-1$ & 30 & $* * *$ \\
\hline & & $1-0.5$ & 30 & $* * *$ \\
\hline & & $0.5-0.25$ & 13.50 & $* * *$ \\
\hline & & $<0.25$ & 15 & $* * *$ \\
\hline & \multirow[t]{4}{*}{2 months } & $2-1$ & 39 & $* * *$ \\
\hline & & $1-0.5$ & 10.50 & $* * *$ \\
\hline & & $0.5-0.25$ & 22.50 & $* * *$ \\
\hline & & $<0.25$ & 13.00 & $* * *$ \\
\hline & \multirow[t]{4}{*}{5 months } & $2-1$ & 30.50 & $* * *$ \\
\hline & & $1-0.5$ & 29.50 & $* * *$ \\
\hline & & $0.5-0.25$ & 67 & $* * *$ \\
\hline & & $<0.25$ & 164 & $*$ \\
\hline & \multirow[t]{4}{*}{7 months } & $2-1$ & 255 & n.s. \\
\hline & & $1-0.5$ & 265 & n.s. \\
\hline & & $0.5-0.25$ & 193 & $*$ \\
\hline & & $<0.25$ & 196 & $*$ \\
\hline & \multirow[t]{4}{*}{9 months } & $2-1$ & 298.5 & n.s. \\
\hline & & $1-0.5$ & 297.5 & n.s. \\
\hline & & $0.5-0.25$ & 299 & n.s. \\
\hline & & $<0.25$ & 225 & n.s. \\
\hline
\end{tabular}

n.s.: non-significant at a $p<0.05 .<0.05^{*}$, and $<0.001^{* * *}$. IAF (immediately after the fire).
(Table 4). Significant differences were also found in SWR between both plots IAF, 2 and 5 months after the fire. Seven months after the fire significant differences were only observed in the finer fractions $(0.5-0.25$ and $<0.25 \mathrm{~mm})$ and 9 months later no significant differences were identified between plots in any of the sieve fractions (Table 3c).

In the unburned plot, for all the sampling dates and aggregate sieve fractions analysed, samples were predominantly wettable (Fig. 4a, c, e, i), with the exception of 7 months after the fire where the finer fraction $(<0.25 \mathrm{~mm})$ samples were classified as "low". In the burned plot the SWR was classified mainly as "low" (Fig. 4b, d, f, h, j). However, SWR was classified as strong and severe IAF in the finer fraction $(<0.25 \mathrm{~mm})$. With time SWR persistence was reduced in all the fractions and 9 months after the fire the samples were all wettable, with SWR $<5$ s (Fig. 4i, j).

\subsection{Correlation between variables}

In the unburned area the correlations between soil Munsell colour value and SOM were always negatively significant $(p<0.05)$. The correlations between soil Munsell colour value and SWR and between SOM and SWR were not significant in any case (Table 5). The correlations between Munsell colour value and SOM in the burned area were negatively significant for all sampling dates. However, the correlations between Munsell colour value and SWR and between SOM and SWR were only significant IAF, 2 , and 7 months after the fire ( 7 months later only in the correlation between Munsell colour value and SWR). The coefficients of correlation decrease with time in all cases (Table 5). The partial correlation results showed that SOM controls the correlation between Munsell colour value and SWR, in the burned plot IAF, 2, and 7 months after the fire. IAF the original correlation was highly significant $(r=-0.81, p<0.001)$, being considerably reduced in the partial correlation $(r=0.41$, $p<0.01$ ), 2 months after the fire the original correlation was significant $(r=0.39, p<0.01)$, disappearing in the partial correlation $(r=0.26, p>0.05)$, and 7 months later the original correlation was significant $(r=0.32, p<0.05)$, decreasing in the partial correlation $(r=0.14, p>0.05)$ (Table 5).

\section{Discussion}

\subsection{Soil Munsell colour value}

Fire darkened the soil in the immediate period after the fire. Incomplete fuel combustion produces black ash (Úbeda et al., 2009), especially in low-severity fires, as in the present one, where the temperatures do not reach high values (Keeterings and Bigham, 2000). Normally, black ash is incorporated into the soil or can be eroded in the weeks following the fire (Pereira et al., 2013b), contributing to the darkening of the soil following the fire and the reduction of Munsell value as observed in this study and in previous reports (Ulery and 
a

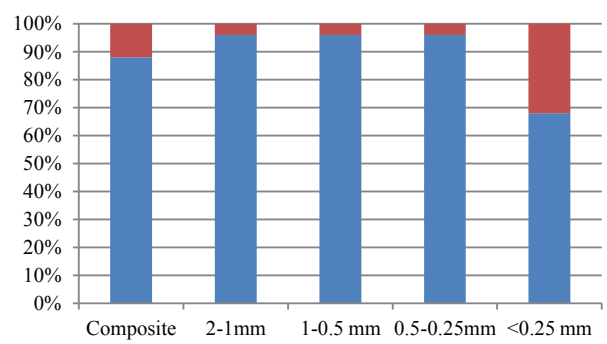

C

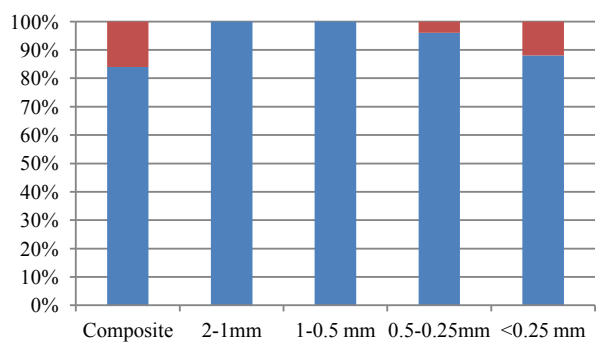

e

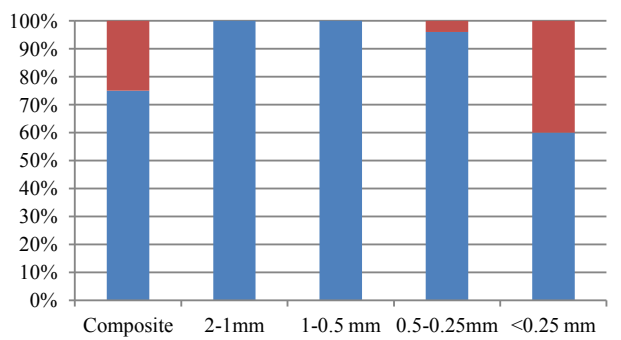

g

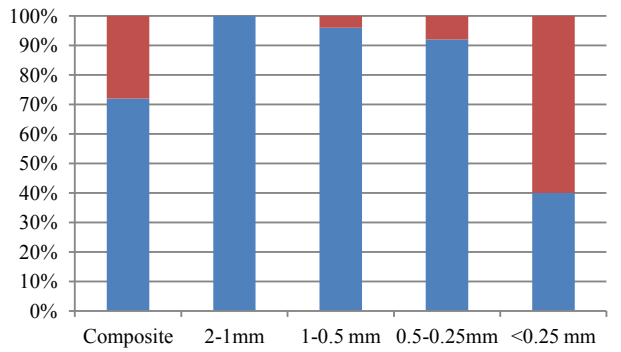

i

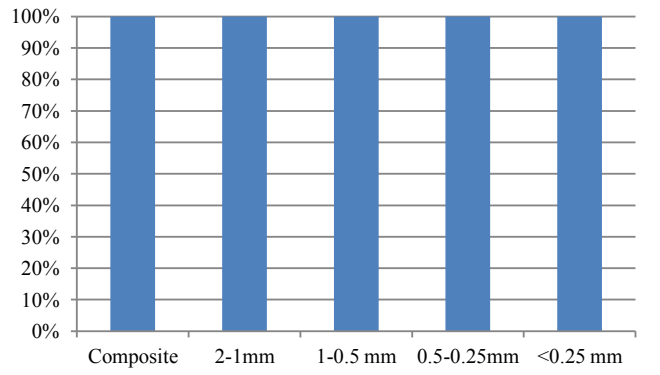

b

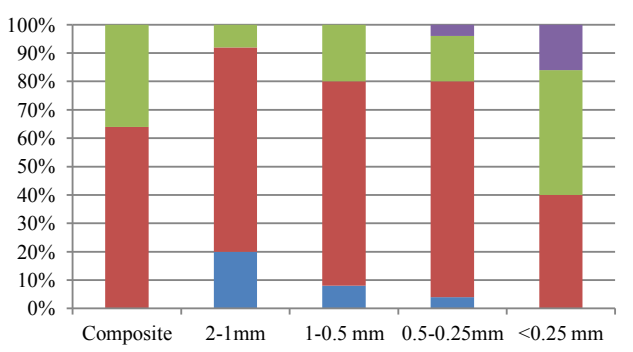

d

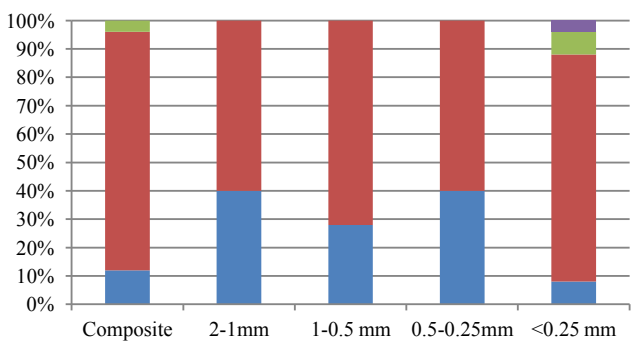

$f$

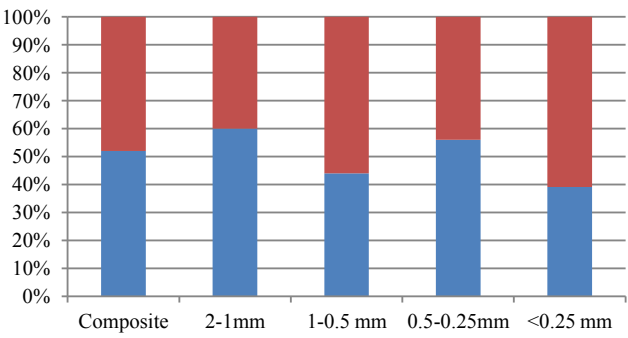

$\mathrm{h}$

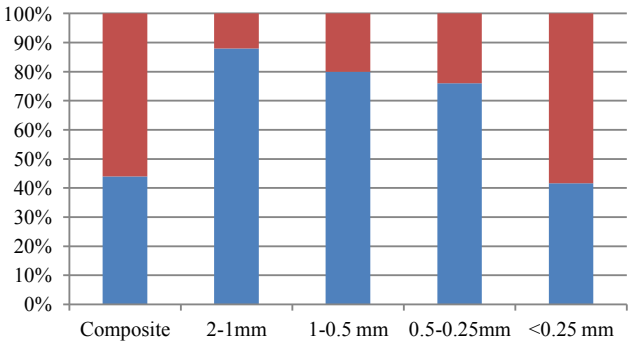

j

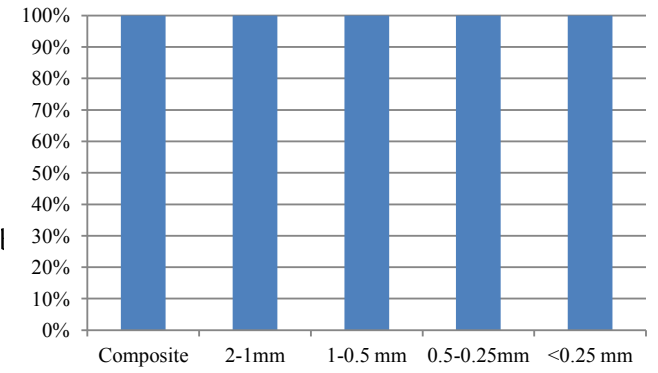

Wettable Low $\square$ Strong $\square$ Severe

Fig. 4. Relative frequency of SWR for composite and sieved soil fractions, (a) unburned, after the fire; (b) burned, after the fire; (c) unburned, 2 months after the fire; (d) burned, 2 months after the fire; (e) unburned, 5 months after the fire; (f) burned, 5 months after the fire; (g) unburned, 7 months after the fire; (h) burned, 7 months after the fire; (i) unburned, 9 months after the fire; and (j) burned, 9 months after the fire. 
Table 4. Water drop penetration time (s) in terms of the different size fractions for unburned and burned plots for different sampling dates. Statistical comparisons were carried out between times (upper case) and in each plot (different fractions in the same plot) during the studied sampling dates (lower case). Different letters represent significant differences at $p<0.05$.

\begin{tabular}{llllll}
\hline $\begin{array}{l}\text { Sampling } \\
\text { date }\end{array}$ & Plots & $2-1 \mathrm{~mm}$ & $1-0.5 \mathrm{~mm}$ & $0.5-0.25 \mathrm{~mm}$ & $<0.25 \mathrm{~mm}$ \\
\hline IAF & Unburned & $1.73(0.78) \mathrm{Ab}$ & $2.02(1.91) \mathrm{Ab}$ & $3.12(7.29) \mathrm{Aab}$ & $15.44(37.42) \mathrm{Aa}$ \\
& Burned & $65.74(133.01) \mathrm{Ab}$ & $101.13(165.66) \mathrm{Ab}$ & $159.65(301.90) \mathrm{Ab}$ & $500.44(657.81) \mathrm{Aa}$ \\
\multirow{2}{*}{2 months } & Unburned & $1.57(0.58) \mathrm{B}$ & $1.62(0.74) \mathrm{A}$ & $1.78(1.36) \mathrm{A}$ & $3.21(4.86) \mathrm{B}$ \\
& Burned & $6.60(4.05) \mathrm{Bb}$ & $12.24(15.14) \mathrm{Bb}$ & $17.88(26.53) \mathrm{Bb}$ & $119.13(237.27) \mathrm{Ba}$ \\
5 months & Unburned & $1.72(0.62) \mathrm{Ab}$ & $1.73(0.61) \mathrm{Ab}$ & $2.69(3.69) \mathrm{Aa}$ & $11.66(16.02) \mathrm{Aa}$ \\
& Burned & $6.70(5.02) \mathrm{Bb}$ & $8.08(7.32) \mathrm{Bb}$ & $9.13(9.86) \mathrm{Cb}$ & $39.33(46.50) \mathrm{Ca}$ \\
7 months & Unburned & $2.12(0.79) \mathrm{Ab}$ & $2.25(1.92) \mathrm{Ab}$ & $2.70(2.42) \mathrm{Ab}$ & $11.93(15.56) \mathrm{Aa}$ \\
& Burned & $3.24(1.89) \mathrm{Cb}$ & $3.61(2.67) \mathrm{Cb}$ & $4.60(4.29) \mathrm{Db}$ & $19.04(25.45) \mathrm{Da}$ \\
9 months & Unburned & $1.05(0.15) \mathrm{B}$ & $1.08(0.22) \mathrm{B}$ & $1.02(0.09) \mathrm{B}$ & $1.33(0.25) \mathrm{B}$ \\
& Burned & $1.10(0.30) \mathrm{Cb}$ & $1.36(1.20) \mathrm{Cb}$ & $1.09(0.34) \mathrm{Eb}$ & $1.57(0.85) \mathrm{Ea}$ \\
\hline
\end{tabular}

Table 5. Coefficients of correlation between the studied variables in the burned area.

\begin{tabular}{|c|c|c|c|c|c|}
\hline $\begin{array}{l}\text { Sampling } \\
\text { date }\end{array}$ & & $\begin{array}{l}\text { Munsell } \\
\text { colour } \\
\text { value } \\
\text { vs. SOM }\end{array}$ & $\begin{array}{l}\text { Munsell } \\
\text { colour } \\
\text { value } \\
\text { vs. SWR }\end{array}$ & $\begin{array}{l}\text { SOM } \\
\text { vs. SWR }\end{array}$ & $\begin{array}{l}\text { Partial } \\
\text { correlation } \\
(\mathrm{SOM})\end{array}$ \\
\hline IAF & $\begin{array}{l}\text { Unburned } \\
\text { Burned }\end{array}$ & $\begin{array}{l}-0.63^{c} \\
-0.74^{c}\end{array}$ & $\begin{array}{l}-0.01^{\text {n.s. }} \\
-0.81^{\mathrm{c}}\end{array}$ & $\begin{array}{l}0.01^{\text {n.s. }} \\
0.75^{\mathrm{c}}\end{array}$ & $\begin{array}{l}\text { n.c. } \\
-0.41^{b}\end{array}$ \\
\hline 2 months & $\begin{array}{l}\text { Unburned } \\
\text { Burned }\end{array}$ & $\begin{array}{l}-0.62^{c} \\
-0.56^{b}\end{array}$ & $\begin{array}{l}-0.01^{\text {n.s. }} \\
-0.39^{\mathrm{b}}\end{array}$ & $\begin{array}{l}0.02^{\text {n.s. }} \\
0.34^{\mathrm{a}}\end{array}$ & $\begin{array}{l}- \text { n.c. } \\
-0.26^{\text {n.s. }}\end{array}$ \\
\hline 5 months & $\begin{array}{l}\text { Unburned } \\
\text { Burned }\end{array}$ & $\begin{array}{l}-0.47^{\mathrm{b}} \\
-0.45^{\mathrm{b}}\end{array}$ & $\begin{array}{l}-0.08^{\text {n.s. }} \\
-0.23^{\text {n.s. }}\end{array}$ & $\begin{array}{l}0.17^{\text {n.s. }} \\
0.22^{\text {n.s. }}\end{array}$ & $\begin{array}{l}\text { n.c. } \\
\text { n.c. }\end{array}$ \\
\hline 7 months & $\begin{array}{l}\text { Unburned } \\
\text { Burned }\end{array}$ & $\begin{array}{l}-0.50^{\mathrm{b}} \\
-0.45^{\mathrm{b}}\end{array}$ & $\begin{array}{l}-0.10^{\text {n.s. }} \\
-0.32^{\mathrm{a}}\end{array}$ & $\begin{array}{l}0.18^{\text {n.s. }} \\
0.17^{\text {n.s. }}\end{array}$ & $\begin{array}{l}\text { n.c. }{ }^{\text {n.s. }} \\
-0.14^{\text {n.s. }}\end{array}$ \\
\hline 9 months & $\begin{array}{l}\text { Unburned } \\
\text { Burned }\end{array}$ & $\begin{array}{l}-0.41^{\mathrm{b}} \\
-0.42^{\mathrm{b}}\end{array}$ & $\begin{array}{l}-0.01^{\text {n.s. }} \\
-0.22^{\text {n.s. }}\end{array}$ & $\begin{array}{l}0.01^{\text {n.s. }} \\
-0.07^{\text {n.s. }}\end{array}$ & $\begin{array}{l}\text { n.c. } \\
\text { n.c. }\end{array}$ \\
\hline
\end{tabular}

Significant at $<0.05^{\mathrm{a}},<0.01^{\mathrm{b}}$ and $<0.001^{\mathrm{c}}$

n.s.: non-significant at a $p<0.05$.

n.c.: partial correlation not calculated due to the lack of correlation between Munsell colour value and SWR.

Graham, 1991). With time, despite the significant differences of soil Munsell colour value between plots, the soil became lighter in the burned plot. This may be attributed to the incorporation of burned residues into the first top centimetres of the soil, reducing soil surface darkness (Eckmeier et al. 2007; Pereira et al., 2012b, c; Woods and Balfour, 2011). The black ash cover has implications in the soil environment in the immediate period after the fire (e.g. temperature and water content). The soil blackening decreases the albedo. This leads to an increase of the soil temperature during the day and a more rapid cooling and heat loss at night (Bowman et al., 2009; Hart et al., 2005; Mataix-Solera et al., 2009; Moody et al., 2013; Scharenbroch et al., 2012). These changes in the soil environment may have effects on the soil temperature and consequently on the microbiological activity, since most biological reactions are related to the temperature. Warmer soils after the fire increase the rates of microbiological processes, such as organic matter decomposition and nutrient release, important to plant recovery (Badia and Marti, 2003; Dooley and Treseder, 2012; Hart et al., 2005; Raison and McGarity, 1980). The change in environmental conditions, together with the nutrient availability, rainfall amount after the fire, and warmer temperatures during the spring season, can explain the fact that 2 months after the fire vegetation recovered completely in this burned area. During this period a total of $88 \mathrm{~mm}$ of rainfall was registered (Pereira et al., 2012a; 2013a). As a result of this, 2 months after the fire the effects of soil colour on soil temperature may have been reduced. As 
in other grassland ecosystems, the fast vegetation recovery is an indicator that the ecosystem is resilient to the impacts of this type of fire (Bond and Parr, 2010; Lewis et al., 2009; Morgan, 1999; Wu et al., 2014).

\subsection{Soil organic matter}

SOM was higher in the burned plot, especially in the first 2 months after the fire. Among sampling dates, a significant difference was only observed in the unburned plot. Previous studies observed that SOM increases in the immediate period after the fire. Vergnoux et al. (2012) identified that in recent fire-affected areas the total organic carbon was significantly higher. In low-severity fires, as in this study, SOM increases temporarily due to the incorporation of ash and charred material into the soil profile (González-Peréz et al., 2004). Short-term increases of SOM in the immediate period after low and medium severity fires were also reported in other studies (De Marco et al., 2005; Gimeno-Garcia et al., 2000; Mataix-Solera et al., 2002; Vogelmann et al., 2012). In this work, during the experimental period significant differences among sampling periods were not observed in the burned plot and this may be related to the fact that the studied plot is located in a flat area and the fast vegetation recovery may have prevented or reduced wind erosion. Soil erosion and SOM transport are accelerated in fire-affected areas due to vegetation removal (Shakesby et al., 2011). Previous studies have shown that losses are high in sloped areas due to water erosion. Gimeno-Garcia et al. (2000) observed that 1 month after an experimental fire carried out in a sloped area, the majority of SOM was washed out due to an extreme rainfall event of more than $30 \mathrm{~mm} \mathrm{~h}^{-1}$. Also, Novara et al. (2011) identified a redistribution and a major accumulation of SOM on the bottom of the slope after a fire in the Valencia region (Spain). The authors attributed this to transport of burned material by surface wash. In the unburned area significant differences among sampling periods were observed, showing that fire might have changed in the short-term the SOM seasonal variation. The lowest value of SOM was observed IAF (April 2011), increasing in the following months. This reduced SOM content in the beginning of the spring season may be attributed to the lack of fresh litter input and reduced biological activity during the winter due to the low temperatures. In summary, this spring fire of low severity increased SOM which may have contributed to the rapid recovery of the vegetation (Pereira et al., 2013a).

The correlation between soil Munsell colour value and SOM was always significantly negative, but especially high in the immediate sampling dates after the fire in both plots. Darker soils correspond to low Munsell values (Viscarra Rosell et al., 2006; Shields et al., 1968; Conant et al., 2011), independently of the area being affected by fire or not. In burned areas, soil became darker with the increasing content of aromatic carbon, present in high amounts in the charred material produced by fires (Dümig et al., 2009). In soils af- fected by low-severity fires, the colour is darker due to the incomplete combustion of organic matter (Terefe et al., 2008).

\subsection{Soil water repellency}

SWR in the fine earth was significantly different among sampling dates in the burned plot until 2 months after the fire, whereas in the unburned plot 9 months after the fire SWR was significantly lower than the previous sampling dates. Fire-induced SWR was reported in previous works in areas affected by low-severity fires (Gleen and Finley, 2010; Granjed et al., 2011; Stoof et al., 2011). Fire changes SWR in previously wettable soils depending on the fuel amount and litter consumed, soil temperature and pre-fire moisture level (Doerr et al., 2000). In this burned plot it is very likely that the direct impacts of fire (e.g. temperature) were minimal since IAF no significant differences were observed in soil moisture between the burned $(14.17 \% \pm 2.83)$ and unburned (13.59\% \pm 2.82 ) plots (Pereira et al., 2012b). In this case, since the temperature impact on the topsoil was probably minimal, the observed increase of SWR in the burned plot can be attributed to the indirect effect of ash deposition on the topsoil. Miranda et al. (1993) observed that during a prescribed fire in an open grassland, at $2 \mathrm{~cm}$ below the soil surface, the temperature ranged from 29 to $38^{\circ} \mathrm{C}$. According to these authors and Heringuer et al. (2002), in grassland fires the soil temperature does not increase importantly and the majority of the heat is lost by convection. Thus, as observed by Vogelman et al. (2012), the increase of soil temperature may not be the responsible for the increase of SWR. The ash produced at low temperature can be hydrophobic (Bodí et al., 2011) and once deposited onto the soil surface can contribute strongly to SWR increases. As in previous works, the ash collected in this burned area (all samples had black colour) was hydrophobic (Pereira et al., 2012a). Ash water repellency is strongly linked to ash chemistry, especially the organic matter content. Dlapa et al. (2013) observed that the wettability of ash decreases with organic matter content. Hydrophobic surfaces are mainly present in organic material, while inorganic material produced at high temperatures is hydrophilic. According to the authors, this explains the different hydrological properties of different types of ash. These results suggested that the incorporation of organic hydrophobic material produced by the fire may have increased temporarily the SWR. In the unburned plot, changes in SWR may be linked with the seasonal variability in this parameter. SWR is a short-term or seasonal phenomenon and depends, among other factors, on climate, the critical soil moisture content above which SWR disappears, texture and organic matter (Doerr et al., 2000; Vogelman et al., 2013). Nine months after the fire (January 2012), the soil was covered by a thick layer of snow and ice. SWR is more severe after dry periods than during wet conditions (Doerr et al., 2000). Buczko et al. (2005) observed in sandy luvisols that SWR was more severe in summer than in autumn/winter. The 
authors attributed this seasonal variability to the organization of organic amphiphilic compounds that changes during wetting and drying cycles according to the seasonal variations of the soil moisture regime. However, the seasonal variability of organic compounds dissolved into the soil solution may also be relevant. Studies carried out by Arye et al. (2007) observed that SWR decreases with the increase of dissolved organic matter leached out by water. In grassland soils, Farrel et al. (2011) observed that soil-dissolved organic carbon was higher in spring than in autumn and winter due to the reduced microbiological activity and the vegetation's seasonal carbon cycles, which have implications for SOM decomposition. Also, according to Kaiser et al. (2001), the soil samples collected in the summertime are richer in hydrophobic compounds than those collected in winter. Further research is needed in order to understand the dynamics of seasonal variation of SWR in boreal grasslands, especially during the wintertime in snow covered soils.

Two months after the fire, SWR decreased substantially in the burned plot, while SOM maintained the same levels during the whole study period. Vogelmann et al. (2012) also observed after a grassland fire an increase of SWR 2 months after the fire, decreasing thereafter. The preservation of SOM levels may be attributed to the rapid vegetation recuperation in the studied area, which maintained the SOM content levels, but vegetation recovery, rainfall, microbiological and invertebrate activity, may contribute to a decrease in the amount of hydrophobic compounds produced by the fire. The biological activity associated with vegetation recovery has implications on the reduction of SWR (Doerr et al., 2009). Knicker et al. (2013) observed that in fire-affected soils where there is no vegetation cover re-establishment and litter input, the different chemical composition of SOM and pyrogenic organic matter increase the SOM aromaticity with reduced solubility. The inputs of fresh litter from vegetation re-establishment replenish SOM and changes soil chemical composition towards that of an area unaffected by fire (Knicker et al., 2013).

In burned areas, previous reports have shown that after a fire, dissolved organic compounds increased in relation to the unburned plot. Michalzik and Martin (2013) observed that after a low-severity prescribed fire in a pine forest, the amount of dissolved organic carbon was significantly higher in the burned plot than in the unburned area. The authors concluded that the leaching of dissolved organic carbon increased measurably after low-severity fires. Similar findings were registered by Zhao et al. (2012) after a prescribed fire in a wetland located in north-eastern China. The authors identified that the dissolved organic carbon was higher in the burned plot than in the unburned plot, until the second growing season after the fire. The solubility of the dissolved organic fractions depends on $\mathrm{pH}$ (Andersson et al., 2000; Impellitteri et al., 2002). Impelliteri et al. (2002) observed that the solubility of humic and fulvic acids in soils increased with increasing $\mathrm{pH}$, while hydrophilic acids remain constant at a $\mathrm{pH}$ range between 3 and 9. The authors found that at a $\mathrm{pH}$ between 3 and 6 the hydrophilic acids dominate the dissolved organic fraction, while at a $\mathrm{pH}$ between 7 and 9, humic acids were the dominant fraction. Humic and fulvic acids are recognized to be potential sources of SWR (Atanassova and Doerr, 2011; Badía-Villas et al., 2013; DeBano, 2000). Humic acids increase in percentage in the humin fraction after laboratory heating and real fires (González-Peréz et al., 2004). The potentially leached material in the burned area may be primarily composed of humic and fulvic acids, very likely leached in the first 2 months after the fire. The soil $\mathrm{pH}$ of the burned plot was in the range of 6.73-7.42 IAF and 7.137.662 months after the fire (not shown), hence favourable to the leaching of fulvic and especially humic acids. In contrast, $\mathrm{pH}$ levels were not the most advantageous to hydrophilic acid leaching. Overall, this may have facilitated the reduction of SWR. Fire induces important changes in $\mathrm{pH}$ and increases nutrient availability due to ash deposition, determining the composition of the microbial community. In the short term, the heat impacts on soil induce microbial mortality. Over the long term, there may be changes in soil microbial communities due to the modification of the plant community and soil environment (Hart et al., 2005). In addition to the direct impact of fire, bacterial activity can be increased in the immediate period after the fire due to increases in soil $\mathrm{pH}$ and dissolved organic compounds (Bárcenas-Moreno et al., 2011). This increase of soluble carbon in fire-affected soils stimulates the recolonization of some microbes such as heterotrophic bacteria and enhances the basal respiration rates (Mataix-Solera et al., 2009). After the fire, the increase of microbiological activity reduces the SWR, due to the decomposition of waxes and hydrophobic material (Franco et al., 2000; Noordman and Jansen, 2002). This activity contributes to the release of organic nutrients immobilized in aromatic compounds present in charred material and fundamental to plant recovery (Knicker et al., 2013). Microbiological activity stimulates root development, plant growth and vice versa (Cheng and Coleman, 1990; Fu and Cheng, 2002; Vessey, 2003). The plant regrowth protects the soil from raindrop impact (Cerdà and Robichaud, 2009) and root development creates new pathways and preferential water flow, increasing the water infiltration (Lange et al., 2009). The invertebrates' activity may also have contributed to the reduction of soil hydrophobic compounds and changed the hydraulic conductivity in the burned plot studied (Fig. 5). To our knowledge there are no studies about the impact of earthworm activity on SWR in burned soils, however, in contaminated areas, it was reported that earthworms have the capacity to take up hydrophobic compounds (Belfroid and Sijm, 1998; Belfroid et al., 1995). A bibliographic review carried out by Blouin et al. (2013) described that earthworm biomass is positively correlated with water infiltration. Earthworm burrows facilitate root penetration and increase hydraulic conductivity. Soil invertebrates can survive easily after grassland fires, since the severity needed to affect them is normally 


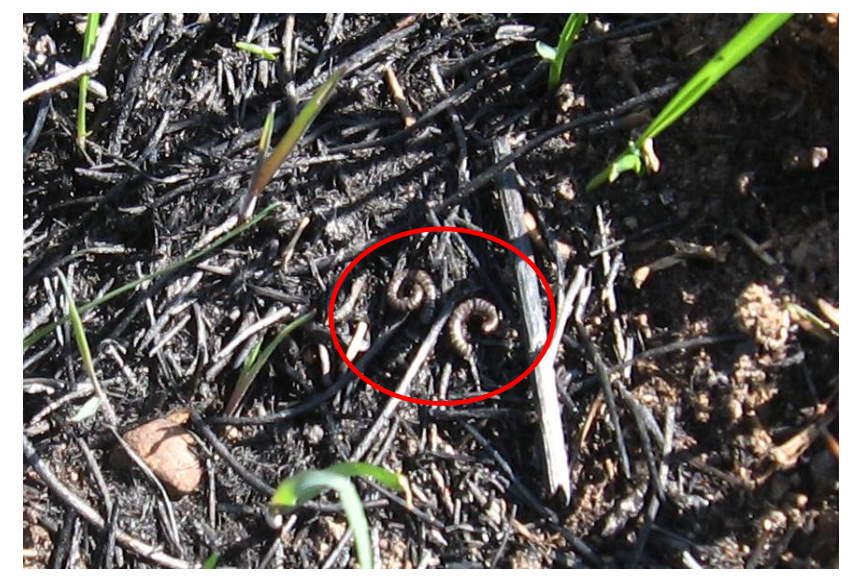

Fig. 5. Evidence of earthworm activity (indicated with a red circle) in the burned plot 17 days after the fire.

not achieved (Neary et al., 1999). Previous studies observed that, in the period between 3 and 16 days after a fire in a grassland area, ants constructed their mounds (Pereira et al., 2013b). In other words, the increase of microbiological activity after the fire may have had impacts on the decomposition of hydrophobic material present in the soil particles and aggregates. In the burned area, the decomposition of this material together with the root development and invertebrate activities may have reduced SWR and increased water infiltration, facilitating the transport of the soluble hydrophobic material. These aspects may have had important effects on the SWR decrease 2 months after the fire in the burned area. Also, post-fire wetting and drying cycles (Doerr et al., 2009) and the exceedance of a "critical soil moisture threshold" (Doerr and Thomas, 2000; Huffman and MacDonald, 2004) are related to the SWR decrease. However, Doerr and Thomas (2000) showed that after wetting, SWR is not necessarily re-established when soil becomes dry again. Other factors involved in SWR reduction may be the spatial organization of amphiphilic molecules (Horne and McIntosh, 2000). Differences of SWR among sample times in each sieve fraction of each plot were identified in the burned and unburned plots. In the burned area the coarser-size fractions (2-1 and $1-0.5 \mathrm{~mm})$ demonstrated significant differences in SWR in the first 7 months after the fire, while in the finer-size fractions $(0.5-0.25$ and $<0.25 \mathrm{~mm})$ significant differences in SWR were observed until 9 months later. This shows that the hydrophobic substances attached to soil fractions disappear faster in the coarser sieve fractions than from the finer ones. This dynamic can be attributed to microbiological activity. Microbes may decompose the organic material at different rates. To our knowledge, no previous works have been conducted on microbial decomposition rates in different size fractions in burned areas. However, Fazle Rabbi et al. (2014) observed in Acrisols collected in a native pasture that the soil organic carbon mineralization was higher in macro-
(250-2000 $\mu \mathrm{m})$ and microaggregates $(53-250 \mu \mathrm{m})$ than in the $<53 \mu \mathrm{m}$ fraction. Fernández et al. (2010) found in non-tilled Entic Haplustoll soils that carbon losses through mineralization were especially observed in intermediate-size fractions (1-4 mm). Wu et al. (2012) identified in grassland soils that microbial biomass and dissolved organic carbon were significantly higher in the $>2000 \mu \mathrm{m}$-size fraction, than in the 0-63 $\mu \mathrm{m}$-size fraction. Also, Jha et al. (2012) observed that water soluble carbon was significantly higher in macroaggregates than in microaggregates. These results may support the hypothesis that the mineralization rates and leaching of hydrophobic organic materials were higher in coarser sieve fractions than in the smaller ones. In relation to the differences observed in the unburned plot, in the coarser (2$1 \mathrm{~mm})$ and the finer fractions $(<0.25 \mathrm{~mm})$ SWR was more persistent IAF, 5 and 7 months after the fire in relation to the other sampling dates, while in the intermediate-size fractions (1-0.5 and $0.5-0.25 \mathrm{~mm}$ ) SWR was significantly lower 9 months after the fire in comparison to the other sampling dates. The intermediate-size fractions followed the same pattern observed for the fine earth. The main differences were identified 2 months after the fire. It is not clear why this difference occurred in the second sampling date after the fire. In the international literature no previous works were found about the seasonal impacts on SWR according to soil aggregate sizes. Further research is needed to identify the factors responsible for these changes.

In the unburned and burned plots, the SWR was high in the finer fraction $(<0.25 \mathrm{~mm})$. The results obtained in this study are in accordance with previous works in unburned (Arcenegui et al., 2008; Urbanek et al., 2007) and burned soils (Mataix-Solera and Doerr, 2004; Gimeno Garcia et al., 2011; Jordán et al., 2011), which identified that the finer soil fraction was more repellent than the coarser fractions. SWR is mainly attributed to soils with coarser textures that are more susceptible to developing repellent surfaces, due to the smaller specific surface area in relation to fine textured soils (Blas et al., 2010; Doerr et al., 2000). However, it has been observed that when a soil is hydrophobic, the finer fraction is usually more water repellent than the coarser ones (Jordán et al., 2011; Mataix-Solera and Doerr, 2004). In the present study SWR was especially severe in the finer fraction in the immediate sampling dates after the fire in the burned area. This can be attributed to the existence of hydrophobic ash smaller than $0.25 \mathrm{~mm}$ and/or the presence of hydrophobic interstitial organic matter that influenced the SWR (MataixSolera and Doerr, 2004). In the fine earth significant differences between plots were only identified in the 2 months after the fire. Nevertheless, between each fraction in the different plots, significant differences were observed in the coarser fractions (2-1 and $1-0.5 \mathrm{~mm}$ ) until 7 months after the fire and in the fine fractions $(0.5-0.25$ and $<0.25 \mathrm{~mm})$ until 9 months after the fire. The time for the burned plot to return to previous conditions depends also on the soil-size fraction because 
the rates of mineralization and/or leaching of organic hydrophobic substances may be not equal.

In the burned area the correlations between the Munsell colour value and SOM with SWR were significant only in the first 2 months after the fire $(7$ months later in the case of Munsell colour value and SWR). In unburned and burned areas SWR can be correlated (Lozano et al., 2013; MartínezZavala and Jordán-López, 2009; Mataix-Solera et al., 2002; Mataix-Solera and Doerr, 2004) or not (Blas et al., 2010) with the amount of SOM. The presence of hydrophobic compounds may be related to a certain type of organic material and not to the total SOM content (Doerr et al., 2000). BadíaVillas et al. (2013) observed a significant positive correlation between SWR and pyrolysed carbon, suggesting that SWR is strongly linked with organic materials produced by fire. Also, SWR may be affected by the ionic strength of the soil solution that induces an approximation of charged functional groups in SOM (Hurraß and Shaumann, 2006). These results suggest that the soil became water repellent from the hydrophobic substances produced during the fire, as organic coatings that covered the soil particles and aggregates that with time were decomposed and leached, especially from the coarser fractions. The significant correlations obtained in the first sampling dates after the fire in the burned plot may be the result of the presence of hydrophobic compounds with dark colour. Nevertheless, the partial correlation results showed that SOM controls the correlation of the Munsell colour value and SWR, IAF, 2 and 7 months after the fire, revealing that the original correlations were spurious. This suggests that SOM characteristics may have influenced the SWR. Other studies observed also that SOM has an important influence on SWR correlation with other variables, such as $\mathrm{pH}$ and the fungi parameters ergosterol- and glomalinrelated soil proteins (Lozano et al., 2013). In fact, SWR must be more controlled by the chemical composition of SOM, than by its amount (DeBano et al., 1970). Horne and McIntosh (2000) observed that SWR was especially determined by amphipathic compounds rather than the organic matter's bulk characteristics. Spielvogel et al. (2004) found that SOM aromatic compounds contribute strongly to the correlation of soil lightness and SOM. The authors observed a strong correlation between soil lightness and aryl C $(r=0.87, p<0.01)$. Also Schmidt et al. (1997) identified that charred material and the presence of aromatic $\mathrm{C}$ had important implications in the negative correlation between soil lightness and SOM. These results suggest that SOM characteristics exert significant control on soil Munsell colour values. Also, a soil with the same Munsell value may have different concentrations of aromatic compounds that increase SWR, such as humic and fulvic acids. This shows that the Munsell colour value may not be a good variable to estimate SWR.

\section{Conclusions}

Fire darkened the soil and increased for a short period the SOM content (first 2 months after the fire). This increase was likely due to the input of partially burned ash into the surface soil that produced an increase in the SWR, due to the characteristics of the burned material. However, this increase was not homogeneous across all aggregate-size fractions. Finer fractions were more water repellent than the coarser ones. In the burned area, the SWR of the finer fractions was more persistent in time ( 9 months after the fire) than in the coarser fractions ( 7 months after the fire). The correlations between Munsell colour value and SOM were negatively significant in all cases in the burned and unburned plots. However, the correlations between Munsell colour value and SWR and Munsell colour value and SOM were only significant in the burned area IAF, 2 and 7 months after the fire (in the last sampling date, only between Munsell colour value and SWR). The partial correlations revealed that the correlation between Munsell colour value and SWR IAF, 2 and 7 months after the fire in the burned plot was strongly controlled by SOM, suggesting that organic matter properties may have implications on SWR.

Future research is needed to understand the persistence of the SWR in different sieve fractions, and the factors that control this dynamic, that may be linked with microbiological activity. The different responses of soil-size fractions to SWR after a fire induce considerable temporal variability of fire impacts on SWR and hydrologically related parameters such as infiltration, runoff and soil erosion.

Acknowledgements. The authors would like to acknowledge the Lithuanian Research Council for financing the project LITFIRE, Fire effects on Lithuanian soils and ecosystems (MIP-48/2011), to Comissionat per a Universitats i Recerca del DIUE de la Generalitat de Catalunya, to the Lithuanian Hydrometereological Service for providing meteorological data, to the Spanish Ministry of Science and Innovation for funding through the HYDFIRE project CGL2010-21670-C02-01, FUEGORED (Spanish network of forest fire effects on soils http://grupo.us.es/fuegored/), and to the Cerdocarpa team for the important suggestions to this manuscript. The authors appreciate the paper's English revision by Deborah Martin. We like to acknowledge the important help of Antonio Jordán, Raul Zornoza, and an anonymous reviewer that improved the quality of this manuscript.

Edited by: J. Bockheim

\section{References}

Agee, J. K.: Prescribed fire effects on physical and hydrologic properties of mixed-conifer forest floor and soil. Report 143, Univ. California Resources Center, Davis, California, 1973.

Andersson, S., Nilsson, S. I., and Saetre, P.: Leaching of dissolved organic carbon (DOC) and dissolved organic nitrogen in mor hu- 
mus as affected by temperature and $\mathrm{pH}$, Soil Biol. Biochem., 32, $1-10,2000$.

Arcenegui, V., Mataix-Solera, J., Guerrero,C., Zornoza, R., MataixBeneyeto, J., and Garcia-Orenes, F.: Immediate effects of wildfires on water repellency and aggregate stability in Mediterranean soils, Catena, 74, 219-226, 2008.

Arye, G., Nadav, Y., and Chen, Y.: Short-term reestablishment of soil water repellency after wetting: effect on capilarity pressuresaturation relationship, Soil Sci. Am. J., 71, 692-702, 2007.

Atanassova, I. and Doerr, S. H.: Changes in soil organic compound composition associated with heat-induced increases in soil water repellency, Eur. J. Soil Sci., 62, 516-532, 2011.

Avery, B. W. and Bascomb, C. L.: Soil survey laboratory methods, Soil Survey Tech. Monogr. No. 6. Rothamsted Exp. Harpenden, UK, 1974.

Badía, D. and Martí, C.: Effect of simulated fire on organic matter and selected microbiological properties of two contrasting soils, Arid Land Res. Manag., 17, 55-59, 2003.

Badía-Villas, D., González-Peréz, J. A., Aznar, J. M., ArjonaGarcia, B., and Marti-Dalmau, C.: Changes in wáter repellency, aggregation amd organic matter of a mollic horizon burned in laboratory: Soil depth affected by fire, Geoderma, 213, 400-407, 2014.

Bárcenas-Moreno, G., Garcia-Orenes, F., Mataix-Solera, J., MataixBenyeto, J., and Baath, E.: Soil microbiological recolonization after fire in a Mediterranean forest, Biol. Fertil. Soils, 47, 261272, 2011

Belfroid, A., van den Berg, M., Seinen, W., Hermens, J., and van Gestel, K.: Uptake, bioavailability and elimination of hydrophobic compounds in earthworms (Eisenia andrei) in fieldcontaminated soil, Environ. Toxicol. Chem., 14, 605-612, 1995.

Belfroid, A. C. and Sijm, D. T. H. M.: Influence of soil organic matter on elimination rates of hydrophobic compounds in the earthworm: Possible causes and consequences, Chemosphere, 37, 1221-1234, 1998.

Blank, R. B., Chambers, J. C., and Zamudio, D.: Restoring riparian corridors with fire: Effects on soil and vegetation, J. Range Manag., 56, 388-396, 2003.

Blas, E., Rodriguez-Alleres, M., and Almendros, G.: Speciation of lipid and humic fractions in soils under pine and eucalyptus forests in northwest of Spain and its effects on water repellency, Geoderma, 155, 242-248, 2010.

Blouin, M., Hodgson, M. E., Delgado, E. A., Baker, G., Brussard, L., Butt, K. R., Dai, J., Dendooven, L., Peres, G., Tondoh, E., Cluzeau, D., and Brun, J. J.: A review of earthworm impact on soil function and ecosystem services. Eur. J. Soil Sci., 64, 161182, 2013.

Bodí, M. B., Mataix-Solera, J., Doerr, S., and Cerdà, A.: Wettability of ash from burned vegetation and its relationship to Mediterranean plant species type, burn severity and total organic carbon content, Geoderma, 160, 599-607, 2011.

Bond, W. J. and Parr, C. L.: Beyond the forest edge: Ecology, diversity and conservation of the grassy biomes, Biol. Conserv., 143, 2395-2404, 2010

Bouyoucos, G. J.: Directions for making mechanical analysis of soils by the hydrometer method, Soil Sci., 42, 225-230, 1936.

Bowman, D. M. J. S., Balch, J. K., Artaxo, P., Bond, W. J., Carlson, J. M., Cochrane, M. A., D’Antonio, C. M., DeFries, R. S., Doyle, J. C., Harrisson, S. P., Johnston, F. H., Keeley, J. A., Krawchuk,
M. A., Kull, C. A., Marston, J. B., Moritz, M. A., Prentice, I. C., Roos, C. I., Scott, A. C., Swetnam, T. W., van der Werf, G. R., and Pyne, S. J.: Fire in the earth system, Science, 324, 481-484, 2009.

Buczko, U., Bens, O., and Huttl, R. F.: Variability of soil water repellency in sandy forest soils with different stand structure under Scots pine (Pinus sylvestris) and Beech (Fagus sylvatica), Geoderma, 126, 317-336, 2005.

Bukantis, A.: Lietuvos klimatas, Vilniaus Universitetas, leidykla, Vilniaus, 1994.

Cerdà, A. and Robichaud, P.: Fire effects on soil infiltration, edited by: Cerdà, A. and Robichaud, P. R., Science Publishers, 81-103, 2009.

Certini, G.: Effects of fire on properties of forest soils: a review, Oecologia, 143, 1-10, 2005.

Certini, G.: Fire as a soil-forming factor, Ambio, 43, 191-195, doi:10.1007/s13280-013-0418-2, 2014.

Certini, G., Nocentini, C., Knicker, H., Arfaioli, P., and Rumpel, C.: Wildfire effects on soil organic matter quantity and quality in two fire-prone Mediterranean pine forests, Geoderma, 167-168, 148-155, 2011.

Cheng, W. and Coleman, D. C.: Effect of living roots on soil organic matter decomposition, Soil Biol. Biochem., 22, 781-787, 1990.

Coetsee, C., Bond, W. J., and February, E. C.: Frequent fire affects soil nitrogen and carbon in an African savanna by changing woody cover, Oecologia, 162, 1027-1034, 2010.

Conant, R. T., Ogle, S. M., Paul, E. A., and Paustian, K.: Measuring and monitoring soil organic carbon stocks in agricultural lands for climate change, Front. Ecol. Environ., 9, 169-173, 2011.

Dangi, S. R., Stahl, P. D., Pendall, E., Cleary, M. B., and Buyer, J. S.: Recovery of soil microbial community structure after fire in a sagebrush-grassland ecosystem, Land Degrad. Dev., 21, 423432, 2010.

DeBano, L. F.: The role of fire and soil heating on water repellency in wildland environments, J. Hydrol., 231-232, 195-206, 2000.

DeBano, L. F., Mann, L. D., and Hamilton, L. D.: Translocation of hydrophobic substances into soil by burning organic litter, Soil Sci. Soc. Am. J., 34, 130-133, 1970.

De Groot, W. J., Flannigan, M. D., and Cantin, A. S.: Climate change impacts on future boreal fire regimes, Forest Ecol. Manag., 294, 35-44, 2013.

De Marco, A., Gentile, A. E., Arena, C., and De Santo, A. V.: Organic matter, nutrient content and biological activity in burned and unburned soil of a mediterranean maquis area of southern Italy, Int. J. Wildland Fire, 14, 365-377, 2005.

Dlapa, P., Bodi, M., Mataix-Solera, J., Cerdà, A., and Doerr, S. H.: FT-IR spectroscopy reveals that ash water repellency is highly dependent on ash chemical composition, Catena, 108, 35-43, 2013.

Doerr, S. H.: On standardising the "Water Drop Penetration Time" and the "Molarity of an Ethanol Droplet" techniques to classify soil hydrophobicity: a case study using medium textured soils, Earth Surf. Process. Landf., 23, 663-668, 1998.

Doerr, S. H. and Thomas, A. D.: The role of soil moisture in controling water repellency: New incidences from forest soils in Portugal, J. Hydrol., 231-232, 134-147, 2000.

Doerr, S. H., Shakesby, R., and Walsh, R. P. D.: Spatial variability of soil hydrophobicity in fire-prone Eucalyptus and Pine forests, Portugal, Soil Sci., 163, 313-324, 1998. 
Doerr, S. H., Shakesby, R. A., and Walsh, R. P. D.: Soil water repellency: its causes, characteristics and hydro-geomorphological significance, Earth-Sci. Rev., 51, 33-65, 2000.

Doerr, D. H., Douglas, P., Evans, R. C., Morley, C. P., Mullinger, N. J., Bryant, R., and Shakesby, R. A.: Effects of heating and postheating equilibrium times on soil water repellency, Aust. J. Soil. Res., 43, 261-267, 2005.

Doerr, S. H., Shakesby, R. A., and MacDonald, L. H.: Soil water repellency: A key factor in Post-fire erosion, edited by: Cerdà, A. and Robichaud, P. R., Science Publishers, 197-223, 2009.

Dooley, S. R. and Treseder, K. K.: The effect of fire on microbial biomass: a meta-analysis of field studies, Biogeochemistry, 109, 49-61, 2012.

Dümig, A., Knicker, H., Schad, P., Rumpel, C., Dignac, M. F., and Kogel-Knabner, I.: Changes in soil organic matter composition are associated with forest encroachment into grassland with longterm fire history, Eur. J. Soil Sci., 60, 578-589, 2009.

Eckmeier, E., Gerlach, R., Skjemstad, J. O., Ehrmann, O., and Schmidt, M. W. I.: Minor changes in soil organic carbon and charcoal concentrations detected in a temperate deciduous forest a year after an experimental slash-and-burn, Biogeosciences, 4, 377-383, doi:10.5194/bg-4-377-2007, 2007.

Farrel, M., Hill, P. W., Farrar, J., Bardgett, R. D., and Jones, D. L.: Seasonal variation in soluble soil carbon and nitrogen across a grassland productivity gradient, Soil Biol. Biochem., 43, 835844, 2011.

Fazle Rabbi, S. M., Wilson, B. R., Lockwood, P. V., Daniel, H., and Young, I. M.: Soil organic carbon mineralization rates in aggregates under contrasting land uses, Geoderma, 216, 10-18, 2014.

Fernández, R., Quiroga, A., Zorati, C., and Noellemeyer, E.: Carbon contents and respiration rates of aggregate size fractions under no-till and conventional tillage, Soil Tillage Res., 109, 103-109, 2010.

Franco, C. M. M., Clarke, P. J., Tate, M. E., and Oades, J. M.: Hydrophobic properties and chemical characterization of natural and water repellent materials in Australian sands, J. Hydrol., 231-232, 47-58, 2000.

$\mathrm{Fu}, \mathrm{S}$. and Cheng, W.: Ryzosphere priming effects on the decomposition of soil organic matter in $\mathrm{C}_{4}$ and $\mathrm{C}_{3}$ grassland soils, Plant Soil, 238, 289-294, 2002.

Gimeno-Garcia, E., Andreu, V., and Rubio, J. L.: Changes in organic matter, nitrogen, phosphorous and cations in soil as a result of fire and water erosion in a Mediterranean landscape, Eur. J. Soil Sci., 51, 201-210, 2000.

Gimeno-Garcia, E., Pascual, J. A., and Llovet, J.: Water repellency and moisture content spatial variations under Rosmarinus officinalis and Quercus coccifera in a Mediterranenan burned soil, Catena, 85, 48-57, 2011.

Gleen, N. F. and Finley, C. D.: Fire and vegetation type effects on soil hydrophobicity and infiltration in sagebrush-steppe: I. Field analysis, J. Arid Environ., 74, 653-659, 2010.

Gomez-Heras, M., Smith, B. J., and Fort, R.: Surface temperature differences between minerals in crystalline rocks: implication for granular disaggregation of granites through thermal fatigue, Geomorphology, 78, 236-249, 2006.

Gomez-Robledo, L., Lopez-Ruiz, N., Melgosa, M., Palma, A. J., Capitan-Vallvey, L. F., and Sanchez-Maranon, M.: Using the mobile phone as Munsell soil-colour sensor: an experiment under controlled illumination conditions, Comput. Electron. Agr., 99, 200-208, 2013.

González-Peréz, J. A., Gonzalez-Vila, F. J., Almendros, G., and Knicker, H.: The effect of fire on soil organic matter - review, Environ. Int., 30, 855-870, 2004.

Granged, A. J. P., Zavala, L. M., Jordán, A., and Bárcenas-Moreno, G.: Post-fire evolution of fire properties and vegetation cover in a Mediterranean heathland after a experimental burning: a 3 year study, Geoderma, 164, 85-94, 2011.

Granstrom, A.: Fire management for biodiversity in the European boreal forest, Scand. J. For. Res., 3, 62-69, 2001.

Harris, W. N., Moretto, A. S., Distel, R. A., Boutton, T. W., and Boo, R. M.: Fire and grazing in grasslands of the Argentinian Caldenal: Effects on plant and soil carbon and nitrogen, Acta Oecol., 32, 207-214, 2007.

Hart, S. C., DeLuca, T. H., Newman, G. S., MacKenzie, M. D., and Boyle, S. I.: Post-fire vegetative dynamics as drivers of microbial community structure, For. Ecol. Manage., 220, 166-184, 2005.

Heringuer, A., Jaques, A. V. A., Bissani, C. A., and Tedesco, M.: Caracteristicas de um latossolo vermelho sob pastagem natural sujeita a accao prolongada do fogo e de practicas alternatyvas de manejo, Cienc. Rural, 32, 309-314, 2002.

Horne, D. J. and McIntosh, J. C.: Hydrophobic compounds in sands in New Zealand - extraction, characterization and proposed mechanisms for repellency expression, J. Hydrol., 231232, 35-46, 2000.

Hurraß, J. and Schaumann, G. E.: Properties of soil organic matter and aqueous extracts of actually water repellent and wettable soil samples, Geoderma, 132, 222-239, 2006.

Hylander, K.: The response of land snail assemblages below aspens to forest fire and clear cutting in Fennoscadian boreal forests, Forest Ecol. Manag., 261, 1811-1819, 2011.

Ibañez-Ascencio, S., Marques-Mateu, A., Moreno-Ramon, H., and Balasch, S.: Statistical relationships between soil colour and soil attributes in semiarid areas, Biosyst. Eng., 116, 120-129, 2013.

Impellitteri, C. A., Lu, Y., Saxe, J. K., Allen, H. E., and Peijnenburg, W. J. G. M.: Correlation of the partitioning of dissolved organic matter fractions with the desorption of $\mathrm{Cd}, \mathrm{Cu}, \mathrm{Ni}, \mathrm{Pb}$, and $\mathrm{Zn}$ from 18 Dutch soils, Environ. Int., 28, 401-410, 2002.

Jha, P., Garg, N., Lakaria, B. L., Biswas, A. K., and Rao, A. S.: Soil and residue carbon mineralization as affected by soil aggregate size, Soil Tillage Res., 121, 57-62, 2012.

Jordán, A., Zavala, L. M., Mataix-Solera, J., Nava, A., and Alanis, N.: Effect of fire severity on water repellency and aggregate stability on Mexican volcanic soils, Catena, 84, 136-147, 2011.

Kadunas, V., Budavicius, R., Gregorauskiene, V., Katinas, V., Kliaugiene, E., Radzevicius, A., and Tareskevicius, R.: Geochemical atlas from Lithuania, first ed., Geological Institute, Vilnius, 1999.

Kaiser, K., Guggenberger, G., Haumaier, L., and Zech, W.: Seasonal variations in the chemical composition of dissolved organic matter in organic forest floor layer leachates of old Scots pine $(\mathrm{Pi}$ nus Sylvestris L.) and European beech (Fagus sylvatica) stands in northeastern Bavaria, Biogeochemistry, 55, 103-143, 2001.

Ketterings, Q. M. and Bigham, J. M.: Soil colour as an indicator of slash-and-burn fire severity and soil fertility in Sumatra, Indonesia, Soil Sci. Soc. Am. J., 64, 1826-1833, 2000.

Kinner, D. A. and Moody, J.: Spatial variability of steady-state infiltration into a two layer soil system on burned hillslopes, J. Hydrol., 381, 322-332, 2010. 
Knapp, A. K., Conrad, S. L., and Blair, J. M.: Determinants of soil $\mathrm{CO}_{2}$ flux from a sub-humid grassland: Effect of fire and fire history, Ecol. Appl., 8, 760-770, 1998.

Knicker, H.: How does fire affect the nature and stability of soil organic nitrogen and carbon, Biogeochemistry, 85, 91-118, 2007.

Knicker, H., Gonzalez-Vila, F., and Gonzalez-Vazquez, R.: Biodegradability of organic matter in fire affected mineral soils of Southern Spain, Soil Biol. Biochem., 56, 31-39, 2013.

Kouki, J., Hyvarinen, E., Lappalainen, H., Martikainen, P., and Simila, M.: Landscape context affects the success of habitat restoration: Large scale recolonization patterns of saproxylic and fireassociated species in boreal forests, Divers. Distrib., 18, 348$355,2012$.

Lange, B., Lüescher, P., and Germann, P. F.: Significance of tree roots for preferential infiltration in stagnic soils, Hydrol. Earth Syst. Sci., 13, 1809-1821, doi:10.5194/hess-13-18092009, 2009.

Lewis, T., Reid, N., Clarke, P. J., and Whalley, R. D. B.: Resilience of a high-conservation-value, semi-arid grassland on fertile clay soils to burning, mowing and ploughing, Austral. Ecol., 35, 461481, 2009.

Lozano, E., Jimenez-Pinilla, P., Mataix-Solera, J., Arcenegui, V., Bárcenas, G. M., González-Peréz, J. A., Garcia-Orenes, F., Torres, M. P., and Mataix-Benyeto, J.: Biological and chemical factors controlling the patchy distribution of soil water repellency among plant species in a Mediterranean semiarid forest, Geoderma, 207-208, 212-220, 2013.

MacDonald, L. and Huffman, E. L.: Post-fire soil water repellency: Persistence and soil moisture thresholds, Soil Sci. Soc. Am. J., 68, 1729-1734, 2004.

Malkinson, D. and Wittenberg, L.: Post-fire induced soil water repellency - Modelling short and long-term processes, Geomorphology, 125, 186-192, 2011.

Marion, G. M., Moreno, J. M., and Oechel, W. C.: Fire severity, ash deposition, and clipping effects on soil nutrients in Chaparral, Soil Sci. Soc. Am. J., 55, 235-240, 1991.

Martínez-Zavala, L. and Jordán-López, A.: Influence of different plant species on water repellency in Mediterranean heathlands, Catena, 76, 215-223, 2009.

Marti-Roura, M., Casals, P., and Romanya, J.: Long-term retention of post-fire soil mineral nitrogen pools in Mediterranean shrubland and grassland, Plant Soil, 371, 521-531, 2013.

Mataix-Solera, J. and Doerr, S.: Hydrophobicity and aggregate stability in calcareous topsoils from fire-affected pine forests in southeasthern Spain, Geoderma, 118, 77-88, 2004.

Mataix-Solera, J., Gomez, I., Navarro-Pedreno, J., Guerrero, C., and Moral, R.: soil organic matter, Int. J. Wildland Fire, 11, 107-114, 2002.

Mataix-Solera, J., Guerrero, C., Garcia-Orenes, F., Bárcenas, G. M., and Torres, M. P.: Fire effects on soil microbiology, edited by: Cerdà, A. and Robichaud, P. R., Science Publishers, 133-175, 2009.

Mataix-Solera, J., Arcenegui, V., Tessler, N., Zornoza, R., Wittenberg, L., Martínez, C., Caselles, P., Perez-Bejarano, A., Malkinsnon, D., and Jordán, M. M.: Soil properties as key factors controlling water repellency in fire affected areas: Evidences from burned sites in Spain and Israel, Catena, 108, 6-13, 2013.
Michalzik, B. and Martin, S.: Effects of experimental duff fires on $\mathrm{C}, \mathrm{N}$ and $\mathrm{P}$ fluxes into the mineral soil at coniferous and broadleaf forest site. Geoderma, 197-198, 169-176, 2013.

Michelsen, A., Andersson, M., Jensen, M., Jensen, M., Kjoller, A., and Gashew, M.: Carbon stocks, soil respiration and microbial biomass in fire-prone tropical grassland, woodland and forest ecosystems, Soil Biol. Biochem., 36, 1707-1717, 2004.

Mierauskas, P.: Policy and legislative framework overview of fire management in Lithuanian protected areas, Flamma, 3, 1-5, 2012.

Miranda, A. C., Miranda, H. S., Dias, I. F. O., and Dias, B. F. S.: Soil and air temperatures during prescribed cerrado fires, J. Trop. Ecol., 9, 313-320, 1993.

Moody, J. A., Shakesby, R. A., Robichaud, P. R., Cannon, S. H., and Martin, D. A.: Current research issues related to post-wildfire runoff and erosion processes, Earth-Sci. Rev., 122, 10-37, 2013.

Morgan, J. W., Defining grassland fire events and the response of perennial plants to annual fire in temperate grasslands of southeastern Australia, Plant Ecol., 144, 127-144, 1999.

Neary, D. G., Klopatek, C. C., DeBano, L., and Ffolliott, P. F.: Fire effects on bellow ground sustainability: a review and synthesis, Forest Ecol. Manag., 122, 51-71, 1999.

Neff, J. C., Harden, J. W., and Gleixner, G.: Fire effects on soil organic matter content, composition, and nutrients in boreal interior Alaska, Can. J. Fore. Res., 35, 2178-2187, 2005.

Neris, J., Tejedor, M., Fuentes, J., and Jimenez, C.: Infiltration, runoff and soil loss in andisols affected by forest fire (Canary Islands, Spain), Hydrol. Process., 27, 2814-2824, 2013.

Nguyen, T. T. and Marschner, P.: Addition of a fine-textured soil to compost to reduce nutrient leaching in a sandy soil, Soil Res., 51, 232-239, 2013.

Noordman, W. H. and Janssen, D. B.: Rhamnolipid stimulates uptake of hydrophobic compounds by Pseudomonas aeruginosa, Appl. Environ. Microbiol., 68, 4502-4508, 2002.

Novara, A., Gristina, L., Bodí, M. B., and Cerdà, A.: The impact of fire on redistribution of soil organic matter on a mediterranean hillslope under maqui vegetation, Land Degrad. Dev., 22, 530536, 2011.

Novara, A., Gristina, L., Ruhl, J., Pasta, S., D’Angelo, G., La Mantia, T., and Pereira, P.: Grassland fire effect on soil organic carbon reservoirs in a semiarid environment, Solid Earth, 4, 381-385, 2013.

Pausas, J. and Keeley, J.: A burning story: The role of fire in the history of life, BioScience, 59, 593-601, 2009.

Pereira, P., Úbeda, X., Martin, D., Mataix-Solera, J., and Guerrero, C.: Effects of a low prescribed fire in ash water soluble elements in a Cork Oak (Quercus suber) forest located in Northeast of Iberian Peninsula, Environ. Res., 111, 237-247, 2011.

Pereira, P., Cepanko, V., Vaitkute, D., Pundyte, N., Pranskevicius, M., Zuokaite, E., Úbeda, X., Mataix-Solera, J., and Cerdà, A.: Grassland fire effects on ash properties and vegetation restoration in Lithuania (North-Eastern Europe), Flamma, 3, 3-8, $2012 \mathrm{a}$.

Pereira, P., Mataix-Solera, J., Ubeda, X., Cerdà, A., Cepanko, V., Vaitkute, D., Pundyte, N., Pranskevicius, M., and Zuokaite, E.: Spring Grassland fire effects on soil organic matter, soil moisture and soil water repellency in Lithuania (North-Eastern Europe). First results. 4th International Congress, Eurosoil 2012, Soil science for the benefit of mankind and environment, 2012b. 
Pereira, P., Cerdà, A., Jordán, A., Bolutiene, V., Úbeda, X., Pranskevicius, M., and Mataix-Solera, J.: Spatio-temporal vegetation recuperation after a grassland fire in Lithuania, Procedia Environ. Sci., 19, 856-895, 2013a.

Pereira, P., Cerdà, A., Úbeda, X., Mataix-Solera, J., Martin, D., Jordán, A., and Burguet, M.: Spatial models for monitoring the spatio-temporal evolution of ashes after fire - a case study of a burnt grassland in Lithuania, Solid Earth, 4, 153-165, doi:10.5194/se-4-153-2013, 2013b.

Pereira, P., Pranskevicius, M., Cepanko, V., Vaitkute, D., Pundyte, N., Úbeda, X., Mataix-Solera, J., Cerdà, A., and Martin, D. A: Short time vegetation recovery after a spring grassland fire in Lithuania. Temporal and slope position effect, Flamma, 4, 1317, 2013c.

Post, D. F., Bryant, R. B., Batchily, A. K., Huete, A. R., Levine, S. J., Mays, M. D., and Escadafal, R.: Correlations between field and laboratory measurments of soil color, edited by: Bigham, $\mathrm{J}$. M. and Ciolkosz, E. J., Soil Science Society of America, 35-49, 1983.

Raison, R. J. and McGarity, J. W.: Effects of ash, heat, and the ashheat interaction on biological activities in two contrasting soils, Plant Soil, 55, 363-376, 1980.

Ravi, S., D’Odorico, P., Wang, L., White, C. S., Okin, G. S., Macko, S. A., and Collins, S. L.: Post-fire resource distribution in desert grasslands: A possible negative feedback on land degradation, Ecosystems, 12, 434-444, 2009a.

Ravi, S., D’Odorico, P., Zobeck, T. M., and Over, T. M.: The effect of fire-induced soil hydrophobicity on wind erosion in a semiarid grassland: Experimental observations and theoretical framework, Geomorphology, 105, 80-86, 2009b.

Rodriguez-Alleres, M., Varela, M. E., and Benito, E.: Natural severity of wáter repellency in pine forest soils from NW Spain and influence of wildfire severity on its persistence, Geoderma, 191, 125-131, 2012.

Sankey, J. B., Germino, M. J., Sankey, T. T., and Hoover, A. N.: Fire effects on spatial patterning of soil properties in sagebrush steppe, USA: a meta analysis, Int. J. Wildland Fire, 21, 545-556, 2012.

Scharenbroch, B. C., Nix, B., Jacobs, K. A., and Bowles, M. L.: Two decades of low-severity prescribed fire increases soil nutrient availability in a Midwestern, USA oak (Quercus) forest, Geoderma, 183-184, 80-91, 2012.

Schmidt, M. W. I., Knicker, P. G., Hatcher, P. G., and Kogel-Knaber, I.: Improvement of ${ }^{13} \mathrm{C}$ and ${ }^{15} \mathrm{~N}$ CPMAS NMR spectra of bulk soils, particle size fractions and organic material treatment with $10 \%$ hydrofluoric acid, Eur. J. Soil Sci., 48, 319-328, 1997.

Schulze, D. G., Nagel, J. L., Van Scoyoc, G. E., Henderson, T. L., Baumgardner, M. F., and Scoot, D. E.: Significance of organic matter in determining soil colors, edited by: Bigham, J. M. and Ciolkosz, E. J., Soil Science Society of America, 71-90, 1993.

Shakesby, R. A.: Post-wildfire soil erosion in the Mediterranean: Review and future research directions, Earth-Sci. Rev., 105, 71100, 2011.

Shapiro, S. and Wilk, M.: An analysis of variance test for normality, Biometrika, 52, 591-561, 1965.

Shields, J. A., Paul, E. A., St. Arnaud, R. J., and Head, W. K.: Spectrophotometric measurement of soil colour and its relationship to moisture and organic matter, Can. J. Soil. Sci., 48, 271-280, 1968.
Spielvogel, S., Knicker, H., and Kogel-Knaber, I.: Soil organic matter composition and soil lightness, J. Plant Nutr. Soil Sci., 167, 545-555, 2004.

StatSoft Inc.: STATISTICA, Version 6.0., Tulsa, OK, 2006.

Stoof, C. R., Moore, D., Ritsema, C. J., and Dekker, L. W.: Natural and fire induced soil water repellency in a Portuguese shrubland, Soil Sci. Soc. Am. J., 75, 2283-2295, 2011.

Terefe, T., Mariscal-Sancho, I., Gomez, M. V., and Espejo, R.: Relationship between soil color and temperature in the surface horizon of Mediterranean soils: A laboratory study, Soil Sci., 170, 495-403, 2005.

Terefe, T., Mariscal-Sancho, I., Peregrina, F., and Espejo, R.: Influence of heating on various properties of six Mediterranean soils. A Laboratory study, Geoderma, 143, 273-280, 2008.

Tessler, N., Wittenberg, L., and Greenbaum, N.: Soil water repellency persistence after recurrent forest fires on Mount Carmel, Israel, Int. J. Wildland Fire, 22, 515-526, 2012.

Thwaites, R.: Color, in: Encyclopedia of Soil Science, second Ed., edited by: Lal, R., 211-214, 2002.

Torrent, J. and Barron. V.: Laboratory measurment of soil colour, edited by: Bigham, J. M. and Ciolkosz, E. J., Soil Science Society of America, 21-23, 1993.

Torrent, J., Schwertmann, U., and Schulze, D. G.: Iron oxide mineralogy of some soils of two river terrace sequences in Spain, Geoderma, 23, 191-208, 1980.

Úbeda, X., Lorca, M., Outeiro, L. R., and Bernia, S.: Effects of s prescribed fire on soil quality in Mediterranean grassland (Prades Mountains, north-east, Spain), Int. J. Wildland Fire, 14, 379-384, 2005.

Úbeda, X., Pereira, P., Outeiro, L., and Martin, D. A.: Effects of fire temperature on the physical and chemical characteristics of the ash from plots of cork oak (Quercus suber), Land Degrad. Dev., 20, 589-608, 2009.

Ulery, A. L. and Graham, R. C.: Forest fire effects on soil colour and texture, Soil Sci. Soc. Am. J., 57, 135-140, 1991.

Urbanek, E., Hallet, P., Feeney, D., and Horn, R.: Watter repellency and distribution and of hydrophilic and hydrophobic compounds in soil aggregates from different tillage systems, Geoderma, 140, 147-155, 2007.

USDA: Soil Survey Laboratory Methods Manual. Soil Survey Investigation Report No. 42. Version 4.0, USDA-NCRS, Lincoln, NE, 693 pp., 2004.

Van Bellen, S., Garneau, M., and Bergeron, Y.: Impact of climate change on forest fire severity and consequences for carbon stocks in boreal forest stands of Quebec, Canada: A Synthesis, Fire Ecol., 6, 16-44, 2010.

Vanha-Majamaa, I., Lilija, S., Ryoma, R., Kotiaho, J. S., LaakaLindberg, S., Lindberg, H., Puttonen, P., Tamminen, P., Toivanen, T., and Kuuluvainen, T.: Rehabilitating boreal forest structure and species composition in Finland through logging, dead wood creation and fire: The EVO experiment, Forest Ecol. Manag., 250, 77-88, 2007.

Varela, M. E., Benito, E., and Blas, E.: Impact of wildfires on surface water repellency in soils of northwest Spain, Hydrol. Process., 19, 3649-3657, 2005.

Vargas, R., Collins, S. L., Thomey, M. L., Johnson, J. E., Brown, R. F., Natvig, D. O. and Friggens, M. T.: Precipitation variability and fire influence the temporal dynamics of soil $\mathrm{CO}_{2}$ efflux in an arid grassland, Glob. Change Biol., 18, 1401-1411, 2012. 
Vergnoux, A., Di Rocco, R., Domeizel, M., Guiliano, M., Doumenq, P., and Theraulaz, F.: Effects of forest fires on water extractable organic matter and humic substances from Mediterranean soils: UV-vis and fluorescence spectroscopy approaches, Geoderma, 160, 434-443, 2011.

Vessey, J. K.: Plant growth promoting rhizobacteria as biofertilizers, Plant Soil, 255, 571-586, 2003.

Viscarra Rossell, R. A., Minasny, B., Roudier, P., and McBratney, A. B.: Colour space models for soil science, Geoderma, 133, 320337, 2006.

Vogelmann, E. S., Reichert, J. M., Prevedello, J., Barros, C. A. P., de Quadros, F. L. F., and Mataix-Solera, J.: Soil hydro-physical changes in natural grassland of southern Brazil subjected to burning management, Soil Res., 50, 465-472, 2012.

Vogelmann, E. S., Reichert, J. M., Prevedello, J., Consensa, C. O. B., Oliveira, A. E., Awe, G. O., and Mataix-Solera, J.: Threshold water content beyond which hydrophobic soils become hydrophilic: The role of soil texture and organic matter content, Geoderma, 209-210, 177-187, 2013.

Wessel, A. T.: On using the effective contact angle and the water drop penetration time for classification of water repellency in dune soils, Earth Surf. Process. Landf., 13, 555-562, 1988.
Whitford, W. G. and Steinberger, Y.: Effects of seasonal grazing, drought, fire, and carbon enrichment on soil microarthropods in a desert grassland, J. Arid. Environ. 83, 10-14, 2012.

Woods, S. and Balfour, V.: The effects of soil texture and ash thickness on the post-fire hydrological response from ash-covered soils, J. Hydrol., 393, 274-286, 2011.

WRB: World Reference base for soil resources 2006, 2nd edition, World Soil Resources Reports, No 103, Food and Agriculture Organization of the United Nations, Rome, 2006.

Wu, G. L., Zhao, L. P., Wang, D., and Shi, Z. H.: Effects of TimeSince-Fire on Vegetation Composition and Structures in SemiArid Perennial Grassland on the Loess Plateau, China, CLEANSoil Air-Water, 42, 98-103, 2014.

Wu, H., Wiesmeier, M., Yu, Q., Steffans, M., Han, X., and KogelKnabner, I.: Labile organic $\mathrm{C}$ and $\mathrm{N}$ mineralization of soil aggregates size classes in semi-arid grasslands as affected by grazing management, Biol. Fertil. Soils, 48, 305-313, 2012.

$\mathrm{Xu}, \mathrm{W}$. and Wan, S.: Water- and plant mediated responses of soil respiration to topography, fire, and nitrogen fertilization in a semiarid grassland in northern China, Soil Biol. Biochem., 40, 679-689, 2008.

Zhao, H., Tong, Q., Lin, Q., Lu, X., and Wang, G.: Effect of fires on soil organic carbon pool and mineralization in Northeasthern China wetland, Geoderma, 189-190, 532-539, 2012. 